\title{
Role of internal waves on mixing, nutrient supply and phytoplankton community structure during spring and neap tides in the upwelling ecosystem of Ría de Vigo (NW Iberian Peninsula)
}

\author{
Marina Villamaña, ${ }^{1 *}$ Beatriz Mouriño-Carballido, ${ }^{1}$ Emilio Marañón, ${ }^{1}$ Pedro Cermeño, ${ }^{2}$ \\ Paloma Chouciño, ${ }^{1}$ José C. B. da Silva, ${ }^{3}$ Patricio A. Díaz, ${ }^{4}$ Bieito Fernández-Castro, ${ }^{1}$ Miguel Gilcoto, ${ }^{5}$ \\ Rocío Graña, ${ }^{5}$ Mikel Latasa, ${ }^{6}$ Jorge M. Magalhaes, ${ }^{3}$ José Luis Otero-Ferrer, ${ }^{1}$ Beatriz Reguera, ${ }^{7}$ \\ Renate Scharek ${ }^{6}$ \\ ${ }^{1}$ Departamento de Ecoloxía e Bioloxía Animal, Universidade de Vigo, Vigo, Pontevedra, Spain \\ ${ }^{2}$ Institut de Ciències del Mar, Consejo Superior de Investigaciones Científicas, Barcelona, Spain \\ ${ }^{3}$ Department of Geosciences, Environment, and Spatial Planning, and Interdisciplinary Centre of Marine and Environmental \\ Research, University of Porto, Porto, Portugal \\ ${ }^{4}$ Centro i mar, Universidad de los Lagos, Camino Chinquihue, km 6, Puerto Montt, Chile \\ ${ }^{5}$ Instituto de Investigacións Mariñas, Consejo Superior de Investigaciones Científicas, Vigo, Spain \\ ${ }^{6}$ Centro Oceanográfico de Gijón, Instituto Español de Oceanografía (IEO), Gijón, Spain \\ ${ }^{7}$ Centro Oceanográfico de Vigo, Instituto Español de Oceanografia (IEO), Vigo, Spain
}

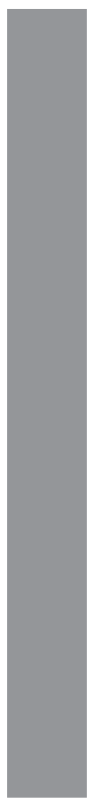

\begin{abstract}
Despite evidence of internal waves in the NW Iberian upwelling region, their action and role on nutrient supply dynamics and phytoplankton community structure remain unexplored. A multidisciplinary approach, combining analysis of Synthetic Aperture Radar (SAR) images acquired during the summer months of 20082011, together with high-frequency samplings carried out in the Ría de Vigo in August 2013 during spring (CHAOS1) and neap tides (CHAOS2), was used to characterize: (1) the internal wave activity, (2) its influence on mixing and nutrient supply, and (3) its role on phytoplankton community. SAR images revealed that internal waves were more energetic during spring tides. Turbulent mixing was higher during CHAOS1-springs $\left(\mathrm{Kz}=1.3\right.$ [1.0-2.0, 95\% confidence interval] $\left.\times 10^{-3} \mathrm{~m}^{2} \mathrm{~s}^{-1}\right)$ compared to CHAOS2-neaps $(\mathrm{Kz}=0.7[0.5-1.0] \times$ $\left.10^{-3} \mathrm{~m}^{2} \mathrm{~s}^{-1}\right)$, and as a result nitrate diffusive fluxes were approximately fourfold higher (35 [17-73] mmol $\mathrm{m}^{-2} \mathrm{~d}^{-1}$ ) during CHAOS1-springs. The sampling covered a transition from relaxation-stratification (CHAOS1springs) to intensifying upwelling (CHAOS2-neaps) conditions, resulting in nitrate supply (including both diffusive and advective fluxes) being about 50\% higher during CHAOS2-neaps. The phytoplankton community, which was overwhelmingly dominated by diatoms in both cruises, exhibited a shift in species composition, with an increase in the abundance of large Chaetoceros spp. during CHAOS2-neaps. About 50\% of the primary production in the ecosystem during periods of upwelling relaxation-stratification could be sustained by enhanced nitrate diffusive fluxes during spring tides. Therefore, even in coastal upwelling regions, turbulent mixing driven by internal waves could play an important role in controlling phytoplankton productivity and community structure.
\end{abstract}

The Rías Baixas are part of the Iberia-Canary Current upwelling domain, one of the main eastern boundary upwelling ecosystems in the global ocean (Arístegui et al. 2009). The most relevant phenomenon in this region is the succession of upwelling and downwelling events in

*Correspondence: mvillamana@uvigo.es

Additional Supporting Information may be found in the online version of this article. accordance with the dominant shelf winds (Wooster et al. 1976; Fraga 1981; Blanton et al. 1987). Northerly winds predominate from April to September causing upwelling. The rise of cold and nutrients rich subsurface waters into the illuminated surface layer in the Rías stimulates the growth of phytoplankton, which supports a highly productive food chain (Fraga 1981; Varela 1992). From October to March the region is under the influence of southerly winds, favorable to downwelling. Despite the seasonal character of both regimes, $70 \%$ of the variability in wind conditions in this area is 
concentrated in periods of less than 30 days (Álvarez-Salgado et al. 2002, 2003), generating a succession of upwellingdownwelling episodes. In each upwelling-downwelling cycle, transitional hydrographic states (defined as spin-up or preparation and spin-down or relaxation events) last typically for around 3-4 days (Álvarez-Salgado et al. 2003; Varela et al. 2005). Thus, a complex small time-scale variability of the hydrographic and biogeochemical conditions is present.

Additionally, during the upwelling season the surface layer is also characterized by marked thermal stratification, which is favorable for internal wave activity and propagation (Moum et al. 2008). The interaction of the surface (or barotropic) tide with bottom topography, either in the open ocean or across the shelf break, results in the generation of internal tides that propagate along the thermocline. These internal tides shorten and steepen as they propagate away from the topography and may originate short period non-linear internal solitary waves (ISWs) or "solitons," which enhance the levels of shear and vertical mixing as they dissipate, particularly during spring tides (Sharples et al. 2007). Enhanced mixing associated with ISWs dissipation increase vertical nutrient transport, which supports horizontal and vertical gradients in phytoplankton community structure, with important implications for fisheries and the export of particulate organic carbon (Sharples et al. 2009; Lucas et al. 2011a,b).

The presence of internal waves at the adjacent shelf off the Ría de Vigo was first described by Fraga (1996), who suggested an increase in mixing levels and nutrient supply to the surface layers as a possible consequence of these features. Barton et al. (2001) described enhanced dissipation rates of turbulent kinetic energy and vertical diffusivity on the shelf edge, around $42^{\circ} \mathrm{N}$, associated with the breaking of internal waves in the thermocline. Moreover, Varela et al. (2005) reported that the internal waves at the adjacent shelf off the Ría de Vigo are not limited to the summer months, when thermal stratification is higher. According to these authors, due to the orientation of the Ría de Vigo in relation to the advancement of the tidal wave (i.e., barotropic Kelvin wave), internal waves penetrate more easily through the south mouth, a feature confirmed by Synthetic Aperture Radar (SAR) images (see Fig. 1). SAR imagery provides details of the two-dimensional spatial structure of internal waves which cannot easily be obtained in situ, including their spatial distribution, orientation and propagation direction (Robinson and da Silva 2010), and also the possibility of calculating a proxy of their associated energy (New and da Silva 2002). This proxy has been commonly used to study internal wave activity in the Bay of Biscay and the western Iberian shelf (New and da Silva 2002; Azevedo et al. 2006; da Silva et al. 2007; Magalhaes and da Silva 2012).

Despite evidence of internal waves in this region, their action and role on nutrient supply dynamics and phytoplankton community composition remain unexplored. A multidisciplinary approach, comprising the analysis of SAR images and intensive sampling of physical, chemical, and biological variables was carried out in the outer part of the Ría de Vigo with the following goals: (1) to characterize internal wave activity during spring and neap tides; (2) to quantify mixing levels and nutrient supply into the photic zone; and (3) to describe the size-structure and composition of the phytoplankton community.

\section{Material and methods}

\section{Energy proxy for internal waves derived from SAR imagery}

A selection of 20 SAR images (8 ERS1\&2-SAR images and 12 Envisat-ASAR in Precision Image mode) acquired during the summer months from 2008 to 2011 was used to characterize the internal wave activity on the shelf off the Ría de Vigo during spring and neap tides. The images were selected to be clearly in spring or neap tides, within a range of $\pm 0.2 \mathrm{~m}$ from the maximum or minimum height of the fortnightly cycle, corresponding to each image date, resulting in 11 images for spring and 9 images for neap tides. In a rectangular area from $42.0^{\circ}$ to $42.4^{\circ} \mathrm{N}$ and $8.9^{\circ}$ to $9.4^{\circ} \mathrm{W}, 32$ and 28 wave packets were identified in spring and neap tides, respectively.

Using the same methodology described by New and da Silva (2002) and Magalhaes and da Silva (2012), a proxy for the energy of the internal waves was defined by analyzing profiles of normalized backscatter SAR intensity. These profiles were taken through the approximate center of the ISW packets and perpendicularly to the wave crests. In order to remove the slant range effect, as part of the usual SAR processing, the normalized backscatter intensity $(K)$ was obtained as:

$$
K=\frac{I-I_{0}}{I_{0}}
$$

where $I$ is the backscattered intensity and $I_{0}$ is a reference background value of intensity, calculated by averaging $I$ over an area of 500 pixels unaffected by ISWs (satisfying the criterion of $95 \%$ confidence level, according to the European Space Agency (ESA) manuals).

From these profiles of normalized backscatter intensity, the amplitude (a proxy for the "strength" of the waves) and the wavelength (a measure of the distance between waves in a packet) were determined, and both parameters were used to calculate an energy proxy for each ISWs packet [see Magalhaes and da Silva (2012) for more details]. This energy proxy was calculated per unit crestlength (labeled $E^{\star}$ ) since we were mostly interested in the vertical mixing generated by internal waves (and not with the lateral, i.e., horizontal, extent of the ISWs produced mixing). The energy proxy, which determines a measure of the total energy per unit crestlength in an ISWs packet, was defined by: 


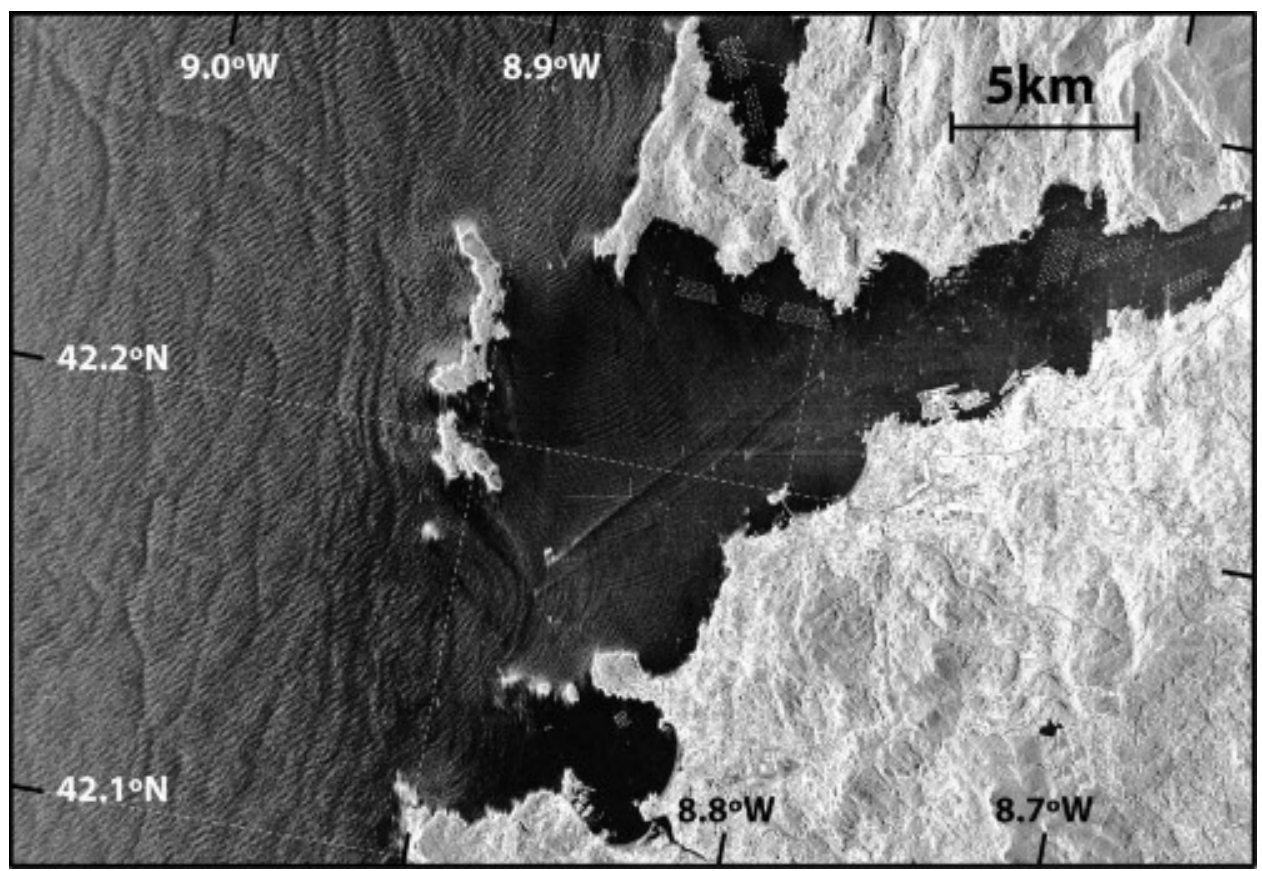

Fig. 1. TerraSAR-X image dated on $05 / 09 / 2011$ and acquired at $18: 26$ UTC, showing an incoming internal wave field propagating generally in the on shore direction, and in which several packets may be seen penetrating through the south mouth of the Ría de Vigo.

$$
E^{*}=\sum_{i=1}^{n} a_{i}^{2} L_{i}
$$

where $n$ is the number of individual waves in the packet, $a$ and $L$ are corresponding amplitudes and wavelength, respectively, as defined above, and $i$ is the indexation variable which indicates the $i^{\text {th }}$ wave in the packet. Since $E^{*}$ does not represent the physical energy in the internal waves packets, but serves as a proxy measure of their "strength," it is considered as a dimensionless parameter.

Since SAR imagery intensity or contrast depends strongly on wind speed and direction (da Silva et al. 1998; Brandt et al. 1999), hourly wind speed data collected from the Cíes $\left(42.38^{\circ} \mathrm{N} 8.93^{\circ} \mathrm{W}\right.$, http://www.meteogalicia.es) and Silleiro $\left(42.12^{\circ} \mathrm{N} 9.43^{\circ} \mathrm{W}\right.$, http://www.puertos.es) meteorological stations were averaged from 08:00 to 13:00 UTC (the images employed were acquired around 11:00 UTC), for all acquisitions of the SAR images. Thus, a single wind speed value was assigned to each image. By doing so, it was assumed that the wind field must be constant over each individual image, since the area over which the observations were made is relatively small (less than $100 \times 100 \mathrm{~km}^{2}$ ) for important variations in wind to occur. Therefore, all the wave packets in a single image were considered as corresponding to the same wind speed. The internal wave packets were assigned to wind speed intervals of $1-3 \mathrm{~m} \mathrm{~s}^{-1}, 3-5 \mathrm{~m} \mathrm{~s}^{-1}$, and 5-7 $\mathrm{m} \mathrm{s}^{-1}$, and the energies computed from the different packets were averaged over each interval.

\section{Field work}

In the framework of the CHAOS (Control of tHe structure of marine phytoplankton cOmmunities by turbulence and nutrient supply dynamicS) project, two cruises were conducted on board the R/V Mytilus in the outer part of the Ría de Vigo during spring (20-21 August 2013, CHAOS1) and neap (27-28 August 2013, CHAOS2) tides. During both cruises, we repeated the same sampling design, which was planned at three different points located approximately along a straight line (see Fig. 2). The outermost station $\left(\mathrm{F} 1,42.131^{\circ} \mathrm{N}, 8.945^{\circ} \mathrm{W}, \sim 80 \mathrm{~m}\right)$ was situated next to R3 and V5, part of the time-series projects RADIALES (Instituto Español de Oceanografía, http://www. seriestemporalesieo.com), and RAIA (Observatorio Oceanográfico da Marxe Ibérica (http://www.marnaraia.org), respectively. At this station, a CTD (Conductivity Temperature Depth, RBR xR620) and a fluorometer (Turner Cyclops7) were attached to a vertically profiling instrument package propelled by ocean waves (WireWalker) during approximately $21 \mathrm{~h}$. At the central station (Mytilus, $42.174^{\circ} \mathrm{N}, 8.890^{\circ} \mathrm{W}, \sim 40 \mathrm{~m}$ ) an intensive sampling (yo-yo) was carried out on board the R/V Mytilus, covering two complete semi-diurnal tidal cycles (ca. $25 \mathrm{~h}$ ), by using a microstructure profiler (MSS). Every hour the yo-yo was interrupted to cast a SBE9/11plus CTD, attached to a rosette of $10 \mathrm{~L}$ hydrographic Niskin bottles, to collect samples for the analysis of inorganic nutrients. Samples for the determination of picoplankton composition were taken from three to five of these casts, whereas for the determination of microphytoplankton community size-structure and composition samples 


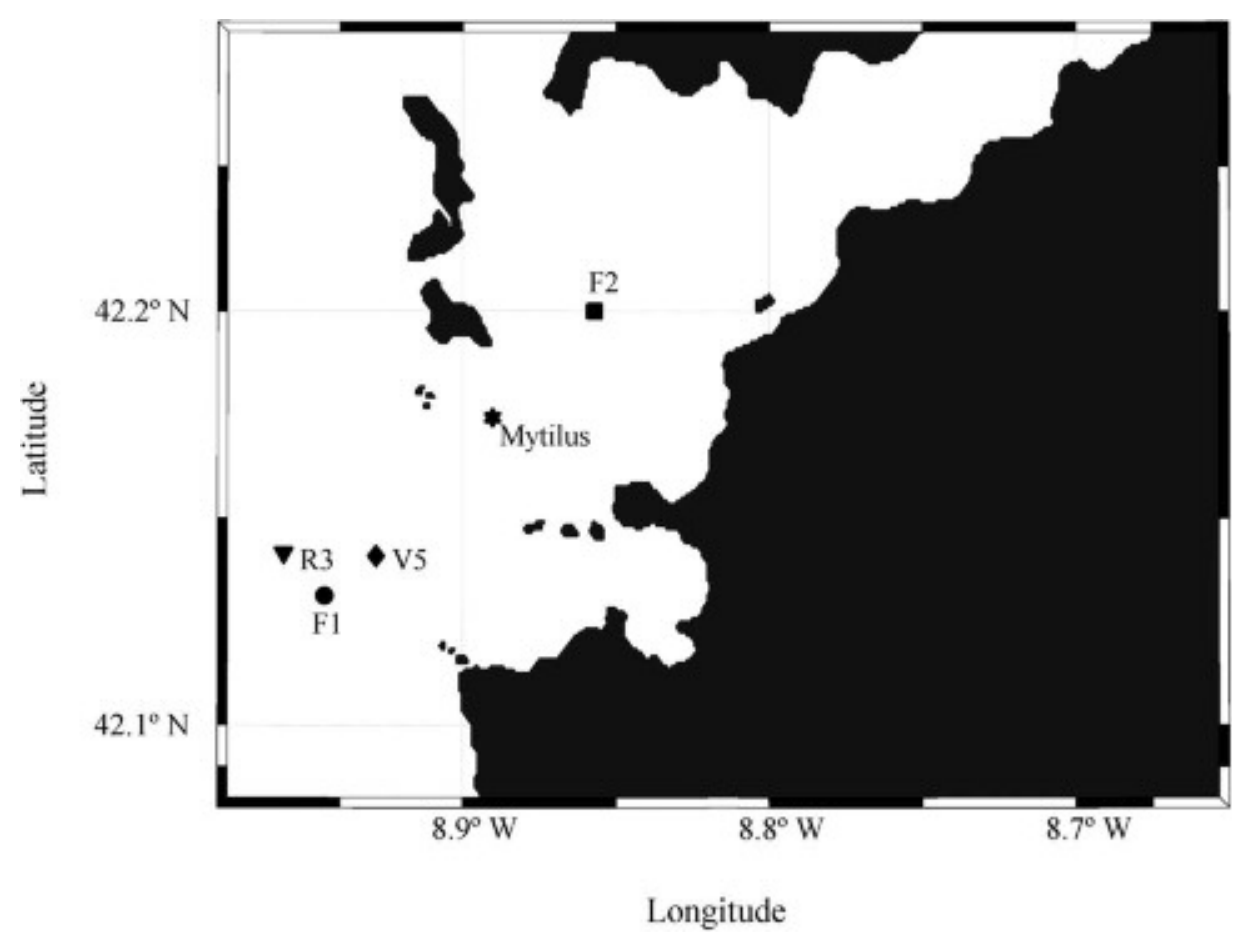

Fig. 2. Map showing the position of the stations sampled during the CHAOS cruises carried out in the outer part of the Ría de Vigo in summer 2013. $\mathrm{F} 1$ indicates the location of the Wire-Walker mooring $\left(42.131^{\circ} \mathrm{N}-8.945^{\circ} \mathrm{W}\right)$, Mytilus the intensive observations carried out on board the R/V Mytilus $\left(42.174^{\circ} \mathrm{N}-8.890^{\circ} \mathrm{W}\right)$, and $\mathrm{F} 2$ the failed AMP profiler $\left(42.2^{\circ} \mathrm{N}-8.857^{\circ} \mathrm{W}\right)$. R3 and V5 correspond to the time-series stations included in the RADIALES and RAIA programs, respectively (see Methods).

were collected at the beginning and the end of each cruise. The third station was located in the inner part of the Ría (F2, $\left.42.2^{\circ} \mathrm{N}-8.857^{\circ} \mathrm{W}, \sim 40 \mathrm{~m}\right)$. The deployment of a multiparameter autonomous AMP-ES-100 profiler was initially planned at this station, but this operation could not be performed due to technical problems.

\section{Microstructure turbulence profiler}

During both cruises yo-yo measurements of microstructure turbulence were obtained by using a MSS (Prandke and Stips 1998) profiler. The profiler was equipped with two microstructure shear sensors (type PNS06), a microstructure temperature sensor (FP07), a high-precision CTD probe including a fluorescence sensor, and a sensor to measure the horizontal acceleration of the profiler. The acquisition and processing of the shear data were performed with the commercial softwares SST-SDA (Standard Data Acquisition) and ProDat Sea \& Sun Technology (www.sea-sun-tech.com/technology.html). Dissipation rates of turbulent kinetic energy $(\varepsilon)$ were computed from the shear data as described in Fernández-Castro et al. (2014). Vertical diffusivity coefficient (Kz) was estimated as:

$$
\mathrm{Kz}=e \frac{\varepsilon}{N^{2}}\left(\mathrm{~m}^{2} \mathrm{~s}^{-1}\right)
$$

where $e$ is the mixing efficiency, here considered as 0.2 (Osborn 1980), and $N^{2}$ the squared Brunt-Väisälä buoyancy frequency.

\section{Inorganic nutrient concentration}

Samples for the determination of inorganic nutrients (nitrate, nitrite, ammonium, phosphate, and silica) were collected from 12 depths of the water column with higher vertical resolution in the nutricline. Samples for nitrate and nitrite were acquired every hour, whereas for ammonium, phosphate and silica were acquired every $8 \mathrm{~h}$. Samples were frozen at $-20^{\circ} \mathrm{C}$ until further determination on land, following the methods described in Grasshoff et al. (1983).

\section{Nitrate vertical diffusive fluxes}

Nitrate vertical diffusive fluxes were calculated, following Fick's law, from the product of the nitrate vertical gradient and the averaged vertical diffusivity coefficient computed from the microstructure profiler. The nitrate gradient was obtained by linearly fitting nitrate concentrations between the base of the mixed layer and $30 \mathrm{~m}$. The mixed layer depth was determined as the depth where sigma- $t$ differs by $0.125 \mathrm{~kg} \mathrm{~m}^{-3}$ from the surface value, resulting in an average depth of 7.7 [7.5-7.9] $\mathrm{m}$ and 9.1 [8.9-9.3] $\mathrm{m}$ for CHAOS1springs and CHAOS2-neaps, respectively. Kz was averaged for the same depth interval. This interval was chosen in order to discard the effect of surface wind forcing and bottom friction, and to focus on the mixing effects driven by internal waves at intermediate depths. Because determinations of nitrate concentration and microstructure turbulence were not conducted simultaneously, averaged $\mathrm{Kz}$ was computed 
in time intervals of $40 \mathrm{~min}, 60 \mathrm{~min}, 80 \mathrm{~min}$, and $100 \mathrm{~min}$ centered on the timing when nutrient sampling was carried out.

\section{Size-fractionated chlorophyll $a(\mathrm{Chl} a)$}

Samples for the determination of size-fractionated Chl $a$ were collected at five depths at the beginning and the end of each cruise. $250 \mathrm{~mL}$ of seawater were filtered sequentially through polycarbonate filters of decreasing pore sizes (20 $\mu \mathrm{m}, 5 \mu \mathrm{m}, 2 \mu \mathrm{m}$, and $0.2 \mu \mathrm{m})$. The filters were frozen at $-20^{\circ} \mathrm{C}$ until analysis on land. Once at the laboratory, the pigments were extracted in $90 \%$ acetone at $-20^{\circ} \mathrm{C}$ during $12 \mathrm{~h}$. The fluorescence due to Chl $a$ was measured using a Turner TD-700 fluorometer previously calibrated with pure Chl $a$. Fluorometrically determined Chl a concentrations were used to calibrate the fluorometer sensors included in the MSS profiler (Chl $a=2.06 \times$ Fluorescence MSS - 0.99; $\left.R^{2}=0.64\right)$, and in the CTD-Rosette (Chl $a=1.49 \times$ Fluorescence CTD $\left.-0.94 ; R^{2}=0.68\right)$, which in turn was used to calibrate the fluorometer in the Wire-Walker package (WW) (Fluorescence $\mathrm{CTD}=49.84 \times$ Fluorescence WW - 0.69; $\left.R^{2}=0.83\right)$.

\section{Photosynthetic pigments composition}

Samples for the determination of photosynthetic pigments were obtained at 12 depths at the beginning and the end of each sampling period. $100 \mathrm{~mL}$ of seawater was filtered through GF/F filters (Whatman, $25 \mathrm{~mm}$ ), and the filter was preserved in liquid nitrogen until later determination by High Performance Liquid Chromatography (HPLC), following the methods described in Zapata et al. (2000) and Latasa (2007). Unfortunately, due to technical problems samples were not collected for photosynthetic pigments from surface layers at the beginning of CHAOS2-neaps.

\section{Microscope analysis}

Water samples for the determination of phytoplankton composition were collected at 12 depths at the beginning and the end of each cruise. $100 \mathrm{~mL}$ of unconcentrated samples were preserved in Lugol's iodine acidic solution. Abundance and taxonomic composition of nano- and microphytoplankton were analyzed under an inverted microscope (Nikon Eclipse 2000) using the method described in Utermöhl (1931). The volume of the sedimentation chambers $(25-50 \mathrm{~mL})$ was chosen after checking the Chl $a$ profiles. Two transects were counted at $\times 400$ magnification to include the smaller and more abundant species. To count larger and less abundant species, the whole surface of the chamber was scanned at $\times 100$ magnification. The detection limit was 20 (in chambers of $50 \mathrm{~mL}$ ) and 40 (in chambers of $25 \mathrm{~mL}$ ) cells $\mathrm{L}^{-1}$.

\section{Flow cytometry}

Picoplankton abundance and cell properties were determined from water samples taken at 12 depths at several casts during each sampling period. $1.8 \mathrm{~mL}$ of seawater were preserved with $1 \%$ paraformaldehyde $+0.05 \%$ glutaraldehyde $(\mathrm{P}+\mathrm{G})$ and frozen at $-80^{\circ} \mathrm{C}$ until later analysis in the laboratory. The abundance, biovolume and composition of picoplankton were determined by a FACSCalibur flow cytometer (Becton \& Dickinson). Autotrophic cells were separated into one group of cyanobacteria (Synechococcus) and two groups of picoeukaryotes (large and small), based on their fluorescence and light scatter signals (SSC) (CalvoDíaz and Morán 2006). Two groups of heterotrophic bacteria were distinguished based on their relative green fluorescence (FL1, $530 \mathrm{~nm}$ ), used as a proxy for nucleic acid content, referred to as high nucleic acid (HNA) and low nucleic acid (LNA) content bacteria. In order to estimate biovolume, an empirical calibration between SSC and cell diameter was used (Calvo-Díaz and Morán 2006), assuming spherical shape for all the groups. Finally, picoplankton biomass was computed using the following volume $\left(\mu \mathrm{m}^{3}\right)$ to carbon conversion factors: pg C cell ${ }^{-1}=0.12 \times \mathrm{V}^{0.7}$ for

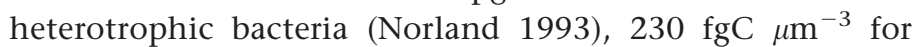
Synechococcus, and $237 \mathrm{fgC} \mu \mathrm{m}^{-3}$ for picoeukaryotes (Worden et al. 2004).

\section{Nitrate vertical advective fluxes}

A simplified estimate of nitrate supply through vertical advection due to upwelling was computed considering the Ría as a single box divided into two layers (Álvarez-Salgado et al. 2000), the deeper one influenced by upwelled water and the surface layer dominated by the outgoing flow. Assuming that the bottom layer volume is conservative and stationary, the vertical advective flux $\left(Q_{Z}, \mathrm{~m}^{3} \mathrm{~s}^{-1}\right)$, would be comparable to the incoming bottom flux $\left(Q_{\mathrm{B}}, \mathrm{m}^{3} \mathrm{~s}^{-1}\right)$, computed as the product of the upwelling index $\left(I_{\mathrm{W}}, \mathrm{m}^{3} \mathrm{~s}^{-1}\right.$ $\mathrm{km}^{-1}$ ) and the length of the mouth of the Ría of Vigo (ca. $10 \mathrm{~km}) . I_{\mathrm{W}}$ was calculated from wind data from the Silleiro buoy (http://www.indicedeafloramiento.ieo.es) and was averaged over the 3 days period before each cruise. Finally, the transport of nitrate into the euphotic zone through vertical advection was computed as:

$$
\mathrm{NO}_{3}^{-} \text {advective flux }=\frac{Q_{z}}{A_{\text {basin }}}\left[\mathrm{NO}_{3}^{-}\right]_{40 \mathrm{~m}}
$$

where $A_{\text {basin }}$ is the surface area of the Ría de Vigo (ca. $\left.174 \mathrm{~km}^{2}\right), Q_{z}$ is the vertical advective flux, and $\left[\mathrm{NO}_{3}^{-}\right]_{40 \mathrm{~m}}$ is the average nitrate concentration at $40 \mathrm{~m}$ determined for each cruise at the central station.

\section{Statistical analyses}

A statistical analysis, based on the identification and counting of 48 samples, was employed to evaluate significant differences in phytoplankton community structure between CHAOS1-springs and CHAOS2-neaps. Non-metric multidimensional scaling (nMDS) based on the Bray-Curtis distance matrix (Legendre and Legendre 1988) was used to assess the similarity of the phytoplankton community 

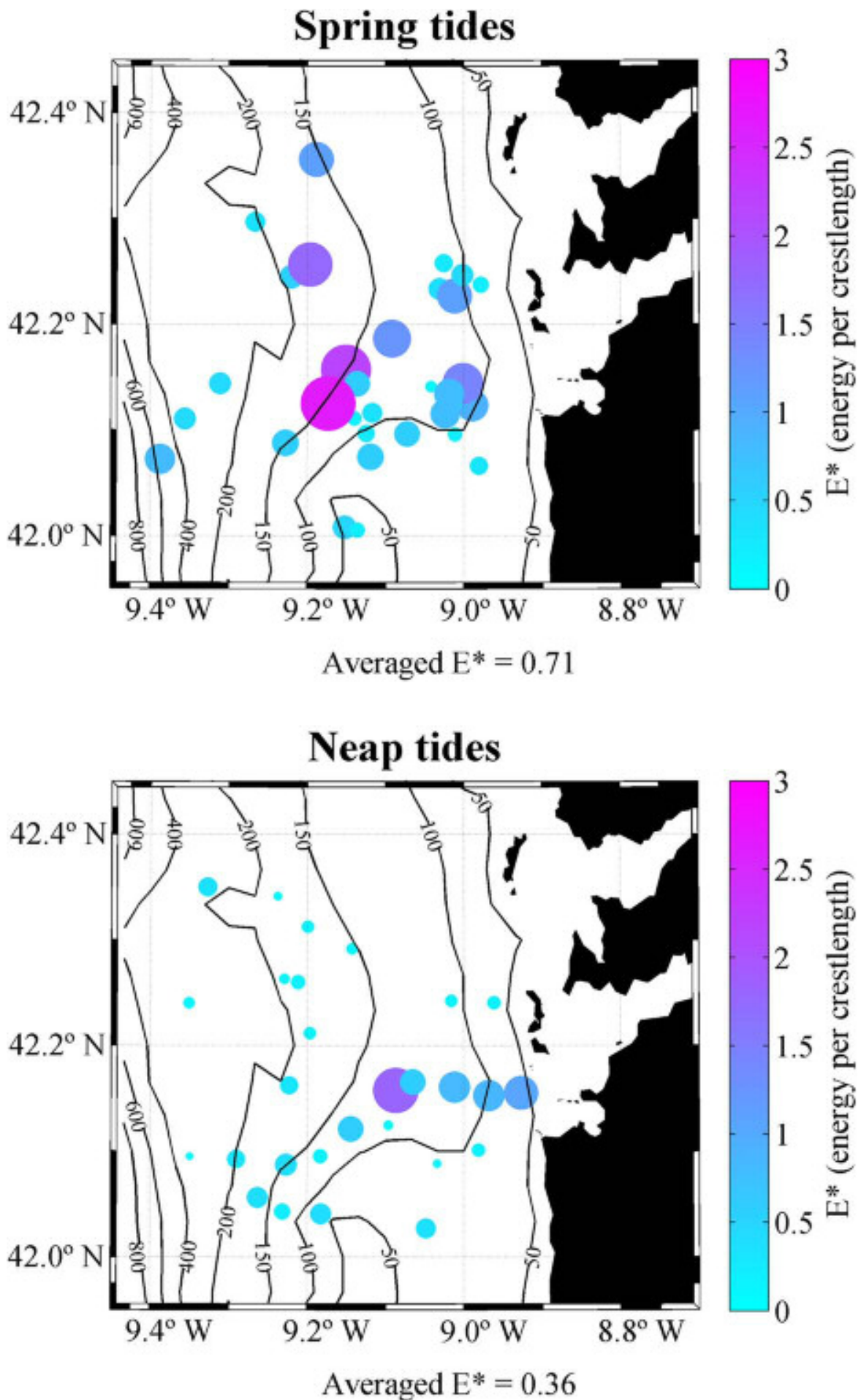

Fig. 3. Distribution of the internal wave packets and their associated energy proxy per unit crestlength ( $E^{\star}$ ) across the shelf off Ría de Vigo during spring and neap tides as derived from the SAR dataset. Both the size and the color of the bubbles indicate the $E^{*}$ value of each individual packet. [Color figure can be viewed at wileyonlinelibrary.com]

composition over the two cruises. To normalize the distribution and eliminate nil values, the data were first logtransformed $[\ln (x+1)]$. Dimensionality was determined by a poorness-of-fit criterion (stress) calculated by determining the square root of a normalized residual sum of squares. Analysis of similarities (ANOSIM, Clarke 1993) was applied 
a)

b)
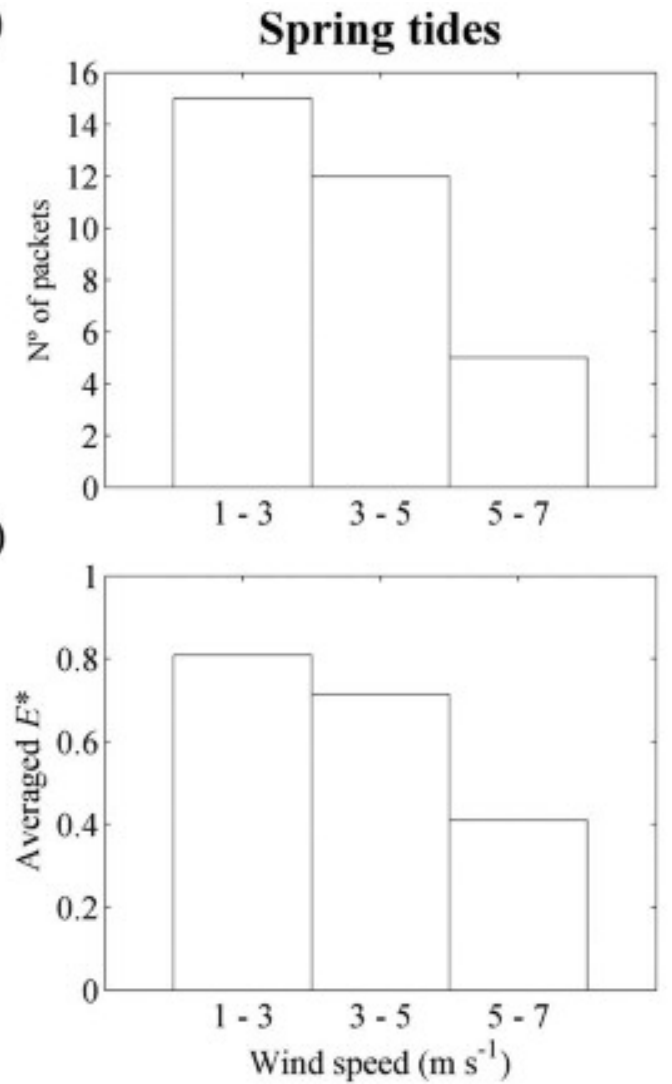

Neap tides
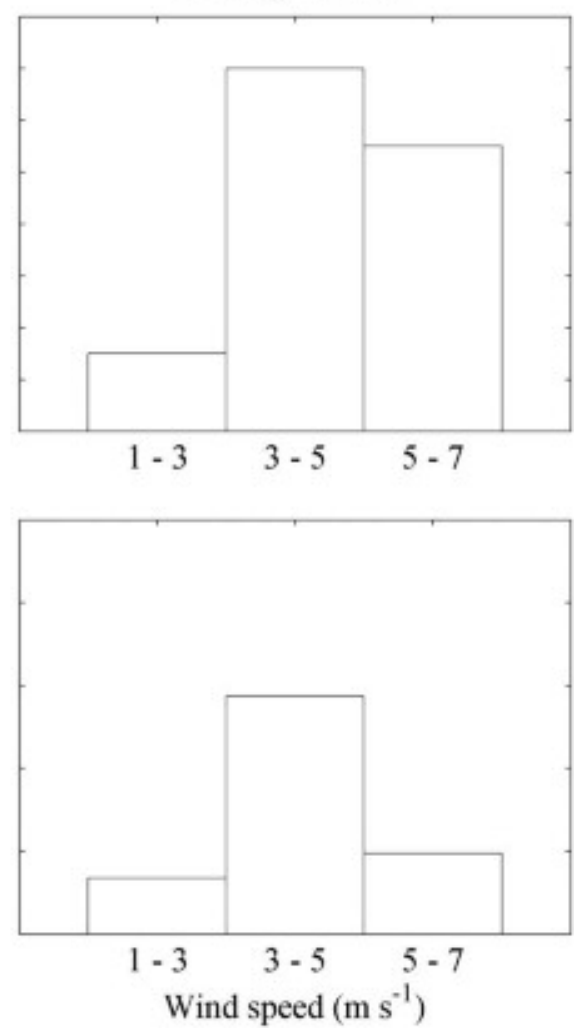

Fig. 4. (a) Frequency of occurrence and (b) averaged values for $E^{*}$, concerning the internal wave packets identified across the shelf off the Ría de Vigo during spring and neap tides as derived from the SAR dataset. Note that in the horizontal axis, wind data were classified by different speed intervals (see Methods).
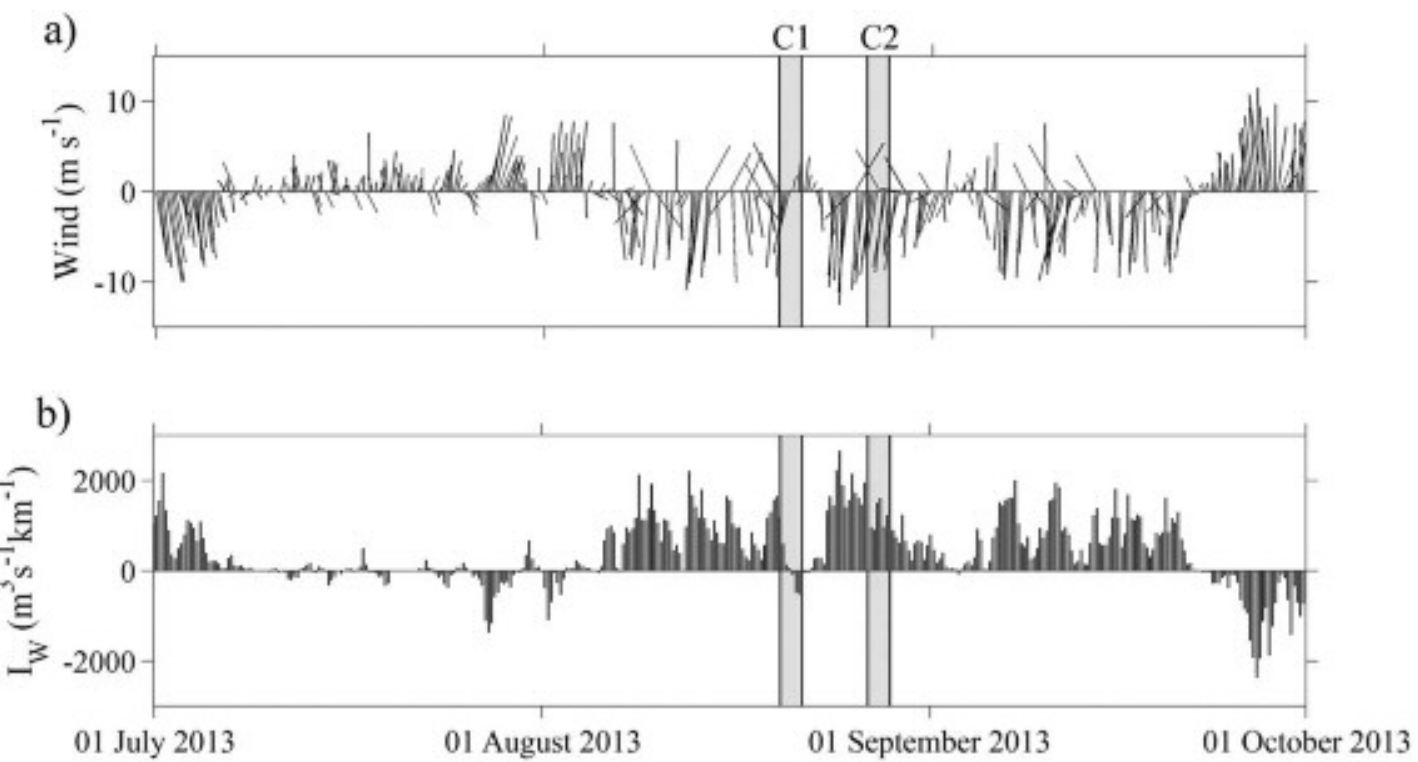

Fig. 5. (a) Vector diagram of wind direction and velocity $\left(\mathrm{m} \mathrm{s}^{-1}\right)$ recorded at the Cabo Silleiro meteorological station $\left(42.12^{\circ} \mathrm{N} 9.43^{\circ} \mathrm{W}\right)$ and $(\mathbf{b})$ upwelling index $\left(I_{W}\right)$ calculated for the same period. Negative (positive) values correspond to northerly (southerly) wind and upwelling (downwelling), respectively. The shaded areas correspond to the CHAOS1 (C1) and CHAOS2 (C2) cruises. 


\section{CHAOS1-Spring tides}
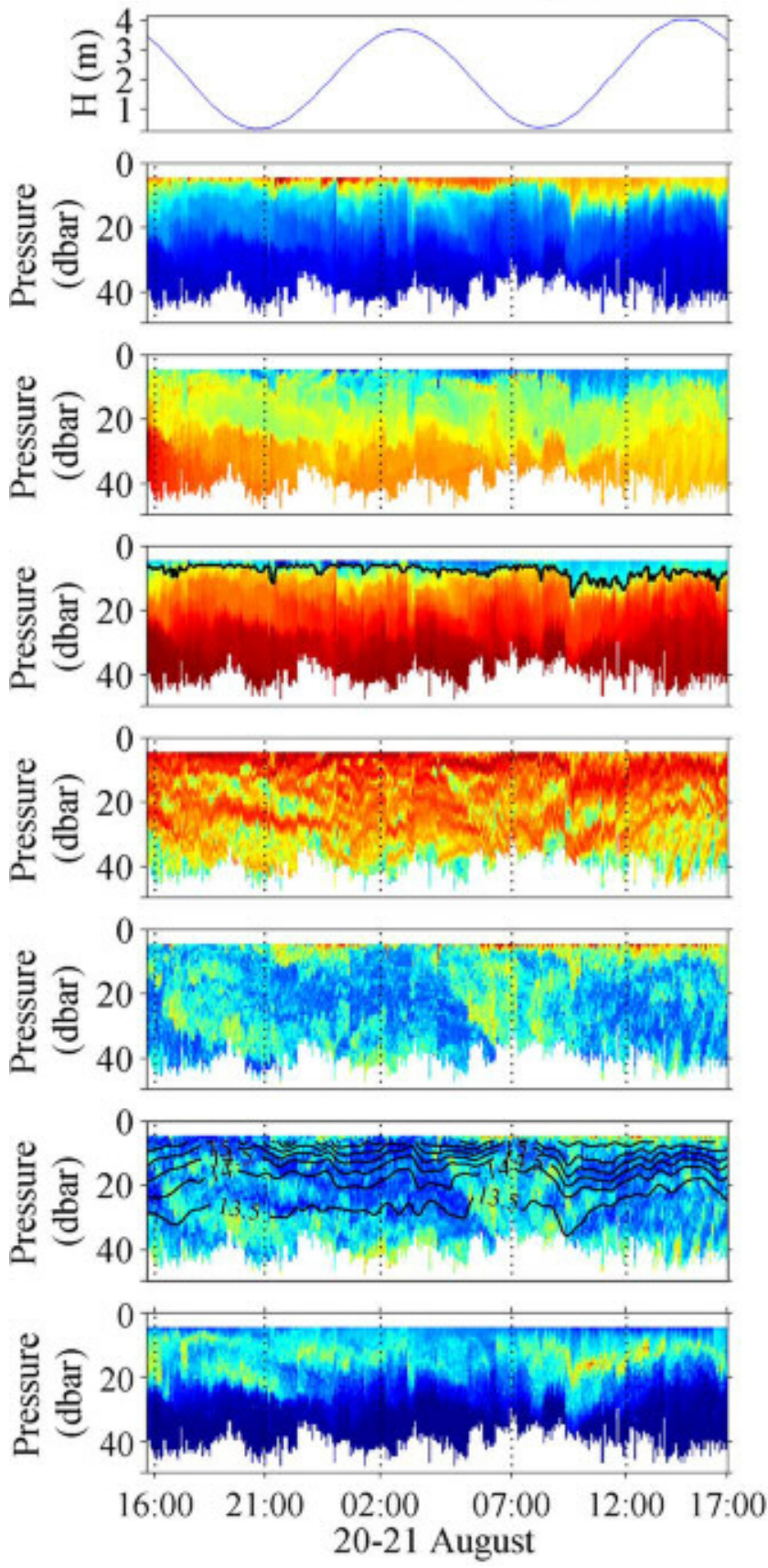

\section{CHAOS2-Neap tides}
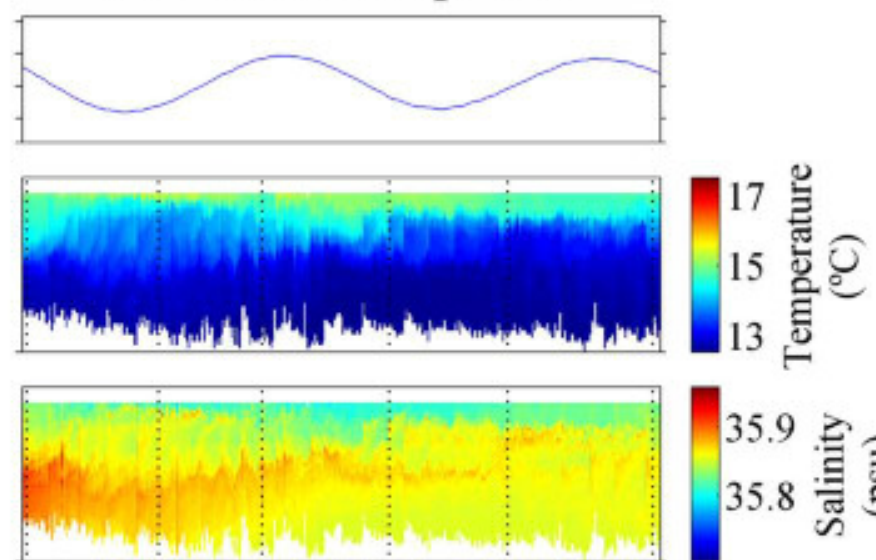

35.9 咅
35.8 营
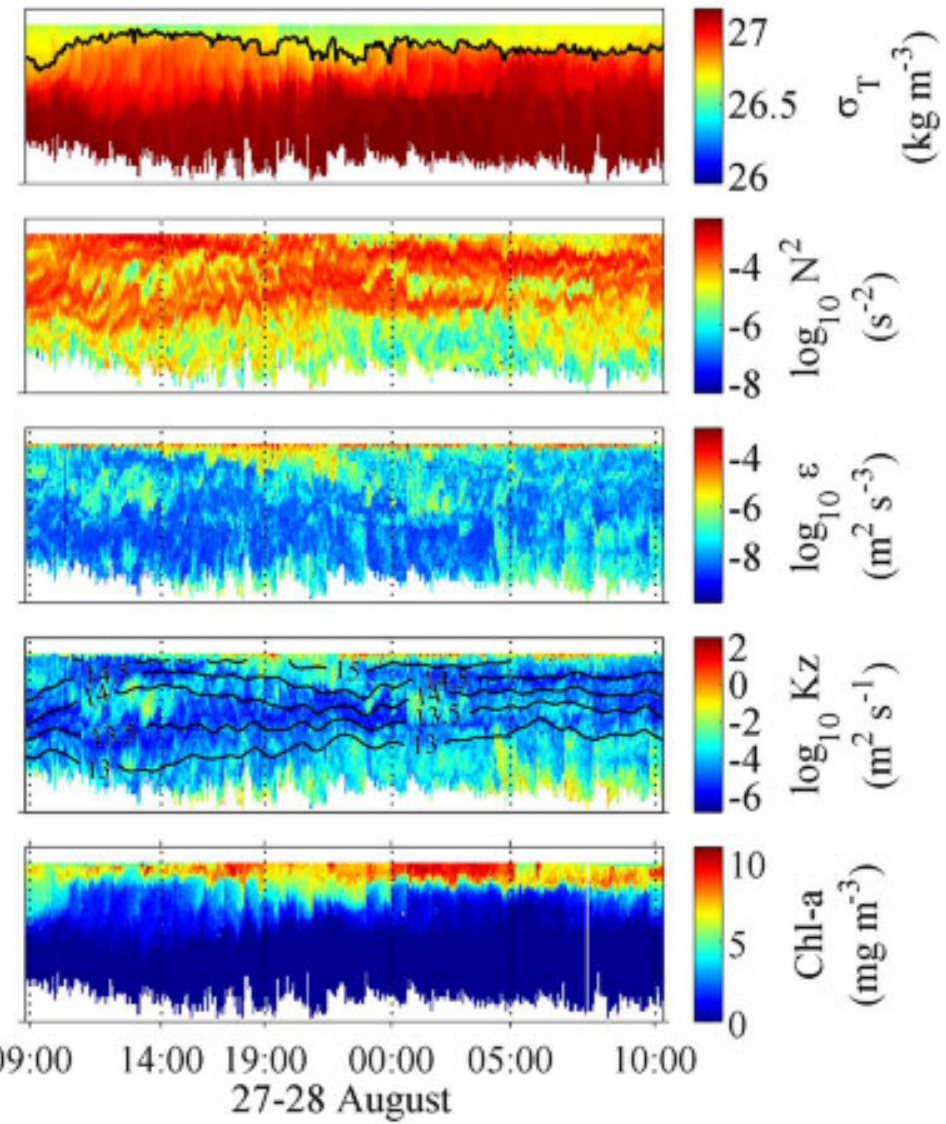

Fig. 6. Vertical distribution of temperature, salinity, sigma-t $\left(\sigma_{t}\right)$, Brunt-Väissälä frequency $\left(N^{2}\right)$, dissipation rate of turbulent kinetic energy $(\varepsilon)$, vertical diffusivity $(\mathrm{Kz})$ and $\mathrm{Chl}$ a derived from the microstructure profiler deployed at the outer part of the Ría de Vigo during spring (CHAOS1) and neap (CHAOS2) tides in August 2013. Tidal height for both periods is represented at the top panels. The solid black line in the sigma- $t$ distribution indicates the mixed layer depth, determined as the depth where $\sigma_{t}$ differs more than $0.125 \mathrm{~kg} \mathrm{~m}^{-3}$ from the surface value. Isotherms are superimposed on the Kz distribution. Horizontal scale corresponds to Coordinated Universal Time (UTC). [Color figure can be viewed at wileyonlinelibrary.com]

to determine differences among sampling depths and cruises. The ANOSIM statistic $\mathrm{R}$ is based on the difference of mean ranks between and within groups. Similarity percentages and species contributions to the differences between the two cruises were estimated using the similarity percentages
(SIMPER, Clarke 1993) method. All statistical analyses were performed using the statistical and programming software $\mathrm{R}$ 2.1.12 (R Development Core Team 2012), "vegan" package, available through the CRAN repository (http://www.r-project.org). 
Table 1. Mean values for selected physical, chemical and biological variables collected during CHAOS1-springs and CHAOS2-neaps cruises. $N^{2}$ (squared Brunt-Väisälä frequency), $\varepsilon$ (dissipation rates of turbulent kinetic energy), and Kz (vertical diffusivity) correspond to averaged values from the base of the mixed layer down to $30 \mathrm{~m}$ depth. The same depth interval was used to compute the vertical nitrate gradient and diffusive fluxes. Chlorophyll ( $\mathrm{Chl}-a$ ) and picoplankton biomass correspond to depth-integrated values for the photic layer. LNA (HNA) is low (high) nucleic acid content bacteria, S_picoEuk small picoeukaryotes and L_picoEuk large picoeukaryotes. Contribution (\%) of four size-fractions to total chlorophyll- $a$ and picoplankton groups to total picoplankton biomass is also indicated. 95\% confidence calculated using a bootstrapping technique are shown in brackets.

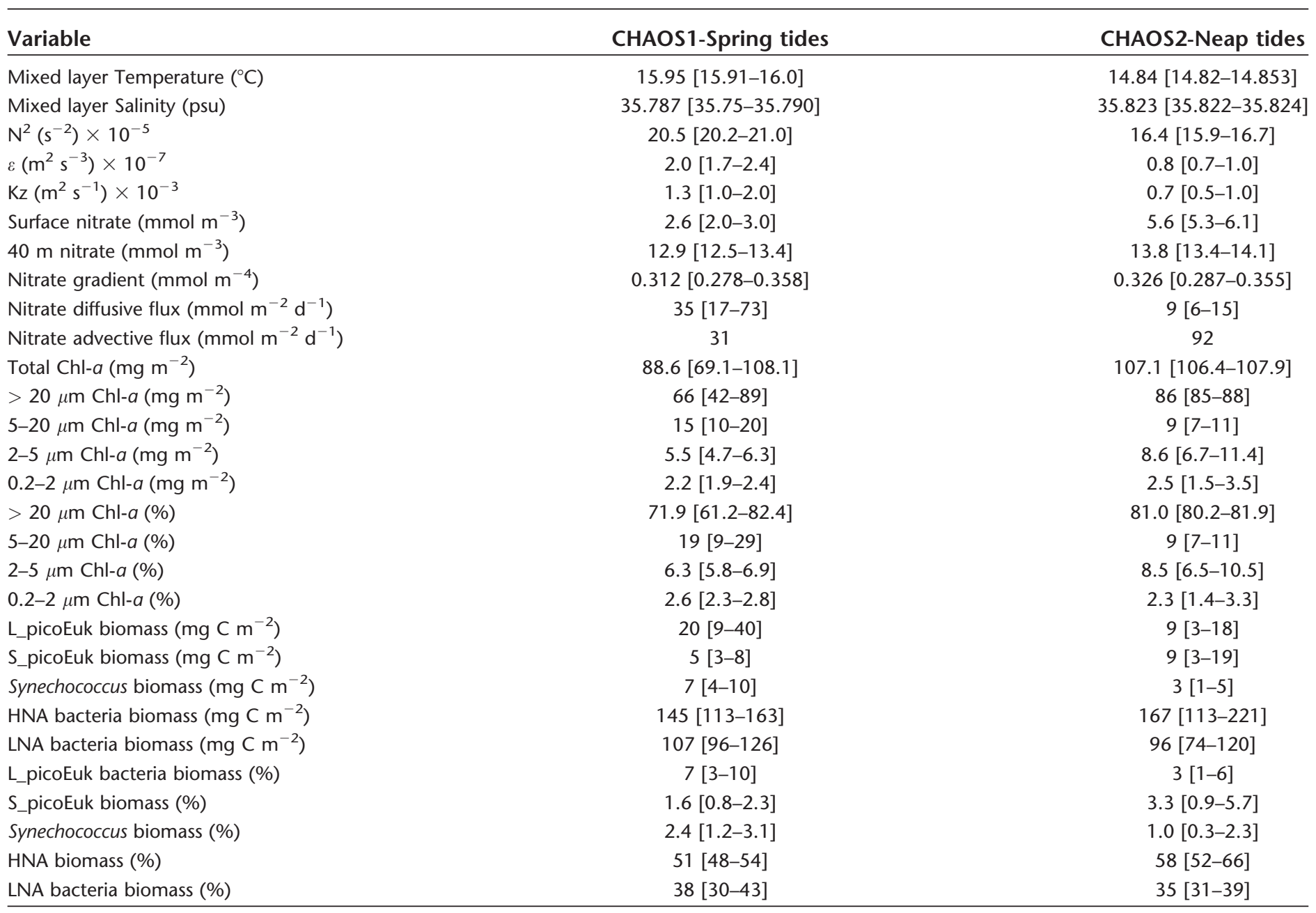

\section{Results}

\section{Internal wave activity in the region during spring and neap tides}

The spatial distribution of the ISW packets and their associated energy proxy estimated from the SAR imagery are shown in Fig. 3. During spring tides a higher number, and more energetic, packets were identified propagating onshore along the entire continental shelf extension, especially between the $100 \mathrm{~m}$ and $150 \mathrm{~m}$ isobaths. During neap tides the packets were generally weaker and scattered throughout the shelf, although the more energetic ones for this period were, in general, located close to the $100 \mathrm{~m}$ isobath. In addition, the averaged energy proxy for spring tides (0.71) was two times higher than for neap tides (0.36). Since the SAR intensity amplitudes can differ due to variations in the wind speed and direction (da Silva et al. 1998; Brandt et al. 1999), energies were averaged together over different wind speed intervals in order to compare energies from images acquired at similar wind speeds (Fig. 4). These results showed that, irrespective of the wind speed interval considered, on average, the ISW energy was higher during spring compared to neap tides. However, caution should be taken at the 1-3 m $\mathrm{s}^{-1}$ interval since fewer waves were averaged for neap tides.

\section{Hydrographic conditions during the field cruises carried out in summer 2013}

During most of July and early August 2013, the region was characterized by transition conditions from relaxation (stratification) to upwelling (Fig. 5). After the first week of 

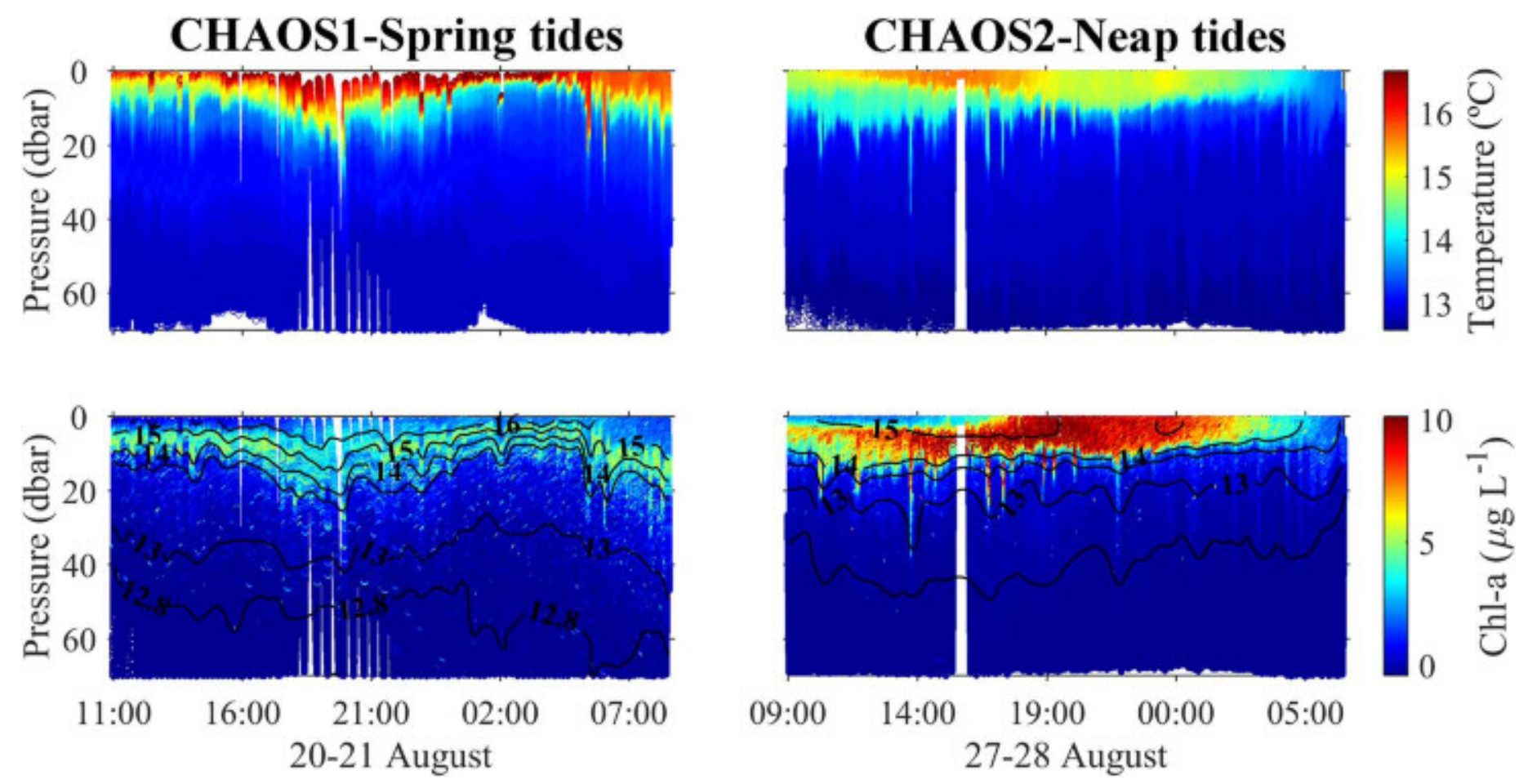

Fig. 7. Vertical distributions of temperature and $\mathrm{Chl} a$ obtained by the Wire-Walker profiler deployed at the outer station $\mathrm{F} 1$ during spring (CHAOS1) and neap (CHAOS2) tides in August 2013. The solid black lines correspond to the isotherms. [Color figure can be viewed at wileyonlinelibrary.com]

August, an intensification of the upwelling was observed (see Supporting Information Fig. 1). However, CHAOS1-springs coincided with a brief and relative decline of the upwelling, which was intense again when CHAOS2-neaps was carried out. The dissimilarities in the upwelling conditions that characterized both cruises caused important differences in the physical, chemical and biological properties of the water column (Fig. 6).

Due to the influence of the upwelling conditions, temperature in the water column was, in general, lower during CHAOS2-neaps compared to CHAOS1-springs. Averaged mixed layer temperatures were $14.84[14.82-14.85]^{\circ} \mathrm{C}$ and 15.95 [15.91-16.0 ${ }^{\circ} \mathrm{C}$ during CHAOS2-neaps and CHAOS1springs, respectively (Table 1). A similar pattern was observed from the data collected by the Wire-Walker profiler, moored at the outer station, where surface temperature dropped from $\sim 16.7^{\circ} \mathrm{C}$ (CHAOS1-springs) to $\sim 15.7^{\circ} \mathrm{C}$ (CHAOS2-neaps) (Fig. 7).

During both cruises relatively high values of dissipation rates of turbulent kinetic energy (c) were observed at the surface and close to the bottom (Fig. 6), due to the wind forcing and the bottom friction, respectively. Also during both periods enhanced values of $\varepsilon$ were observed at intermediate depths close to the low tide. This increase in microturbulence levels was more intense during spring tides, when enhanced $\varepsilon$ values were observed throughout the water column for about $5 \mathrm{~h}$, whereas during neap tides increased $\varepsilon$ values were observed over a narrower depth interval (ca. 10-25 $\mathrm{m}$ ) and a shorter period ( $3 \mathrm{~h})$. Averaged dissipation rates in the water column, computed between the base of the mixed layer and $30 \mathrm{~m}$, were significantly higher during spring (2.0 [1.7-2.4] $\left.\times 10^{-7} \mathrm{~m}^{2} \mathrm{~s}^{-3}\right)$ compared to neap tides $\left(0.8[0.7-1.0] \times 10^{-7} \mathrm{~m}^{2} \mathrm{~s}^{-3}\right)$. The distribution of vertical diffusivity $(\mathrm{Kz})$ in the water column, which depends on both $\varepsilon$ and vertical stratification $\left(N^{2}\right)$ (see Methods), was very similar to the pattern described for dissipation rates. Higher values of $\mathrm{Kz}$ were observed at the surface and close to the bottom, and at mid-depths close to the low tide. This increase was also more intense during spring tides. As a result, averaged $\mathrm{Kz}$ in the water column was significantly higher during spring (1.3 [1.0-2.0] $\left.\times 10^{-3} \mathrm{~m}^{2} \mathrm{~s}^{-1}\right)$ compared to neap tides $(0.7$ [0.5-1.0] $\left.\times 10^{-3} \mathrm{~m}^{2} \mathrm{~s}^{-1}\right)$. The higher influence of the tidal wave during spring tides was clearly visible from the temperature and Chl a vertical distributions sampled at the outer station (Fig. 7). This signal was less visible at the central station, where more intense vertical isotherm displacements, of about $10 \mathrm{~m}$ at relatively short time intervals (ca. 25-50 min), were observed during CHAOS1springs (Fig. 6).

Inorganic nutrient concentration and nitrate supply

Due to the intensifying upwelling conditions, nitrate concentration was higher during CHAOS2-neaps (Fig. 8a). During this cruise, averaged surface and deep $(40 \mathrm{~m})$ 
a) CHAOS1-Spring tides
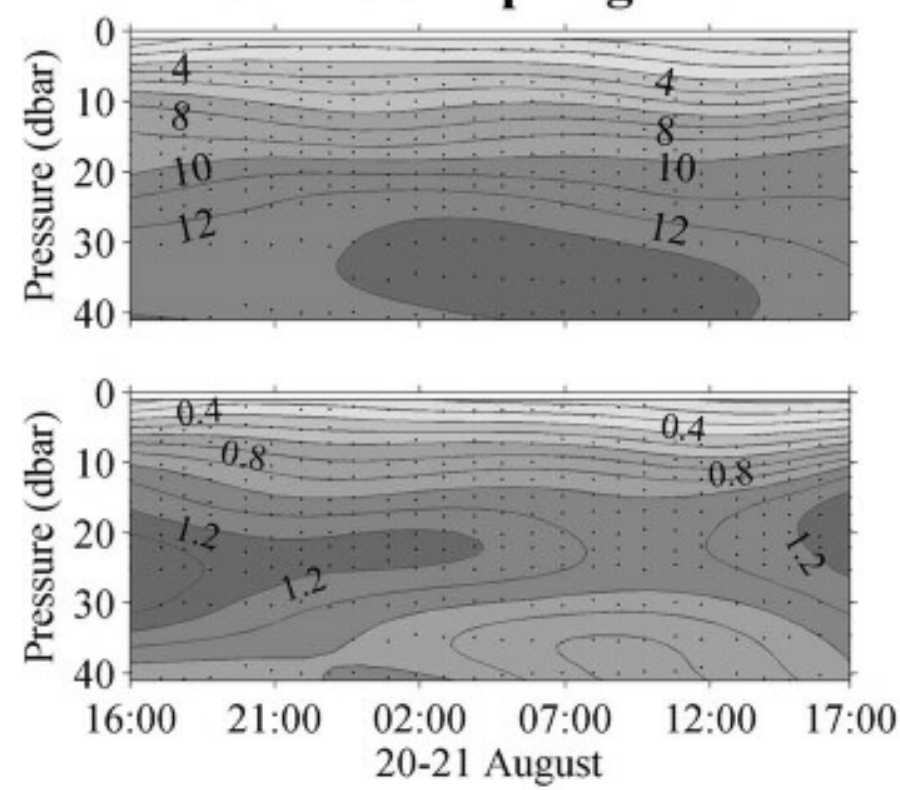

CHAOS2-Neap tides
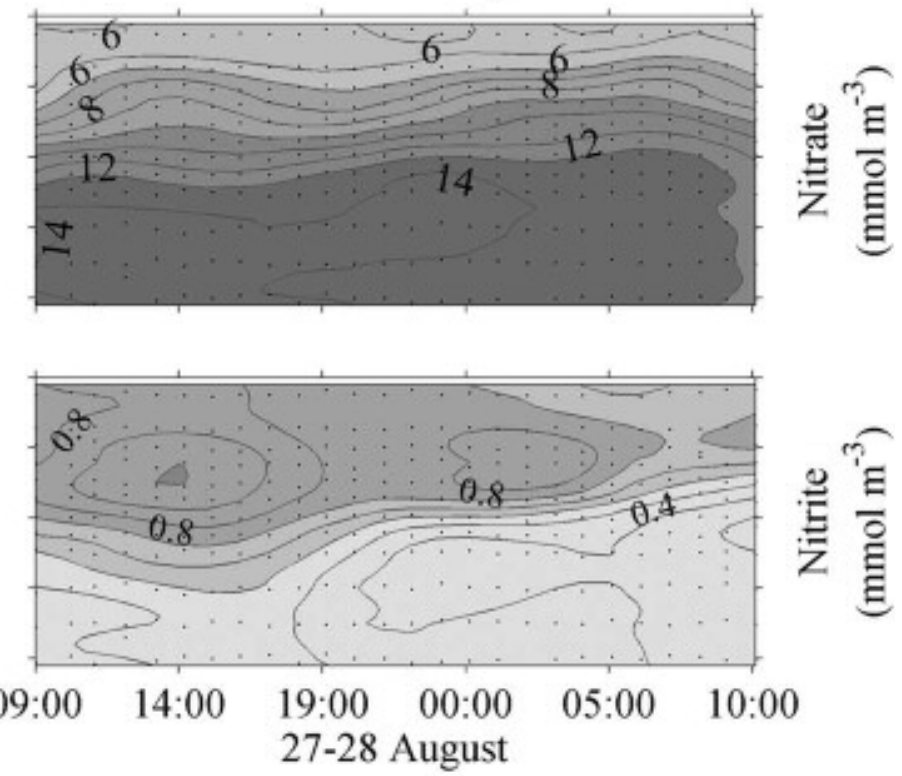

b)
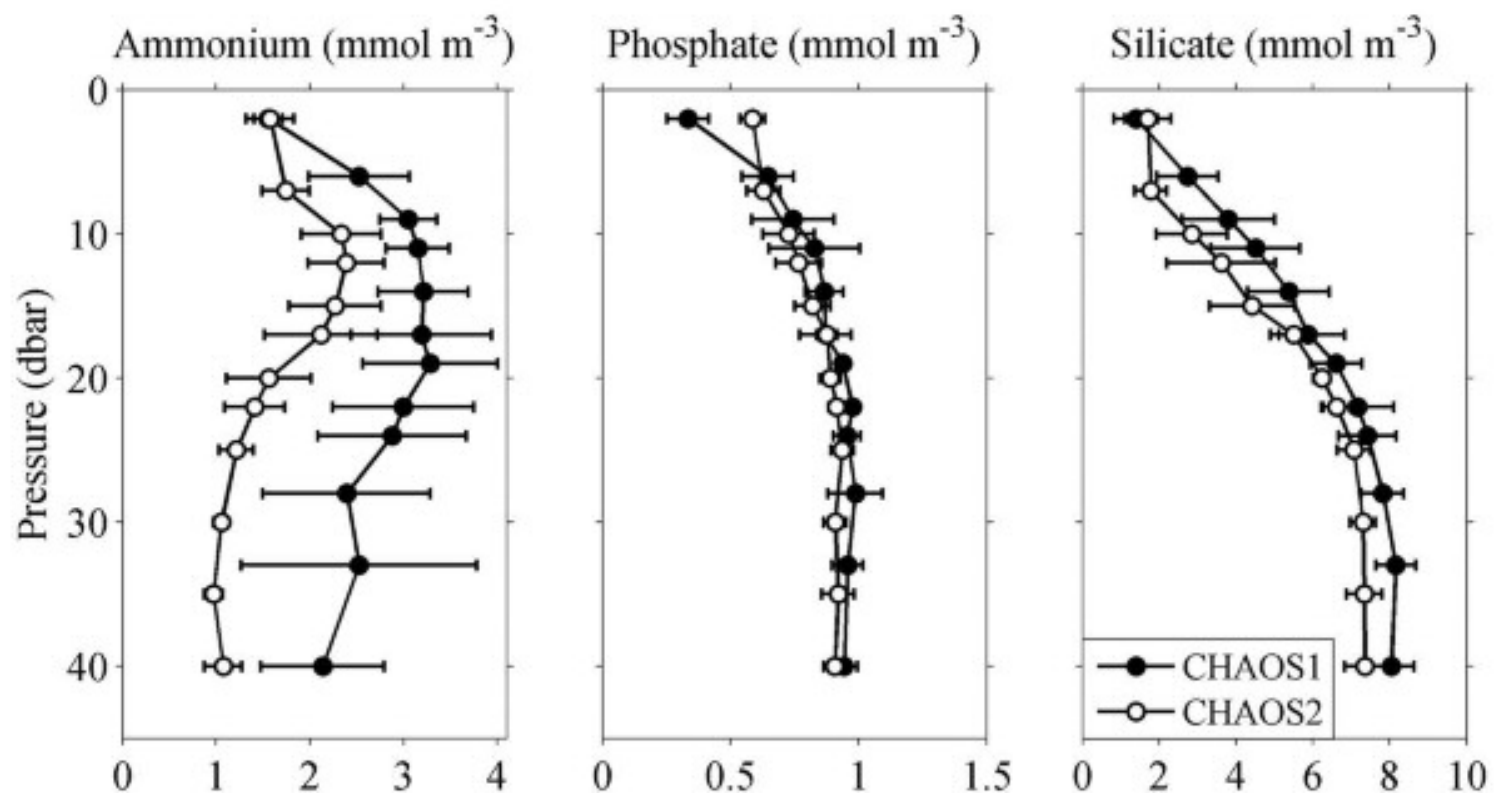

Fig. 8. (a) Vertical distribution of nitrate and nitrite and (b) averaged vertical profiles of ammonium, phosphate, and silicate concentrations determined during spring (CHAOS1) and neap (CHAOS2) tides. Horizontal scale corresponds to Coordinated Universal Time (UTC) and error bars to standard deviation in the upper and lower figure, respectively.

concentrations were 5.6 [5.3-6.1] and 13.8 [13.4-14.1] $\mu \mathrm{mol}$ $\mathrm{L}^{-1}$, respectively, compared to $2.6[2.0-3.0]$ and 12.9 [12.513.4] $\mu \mathrm{mol} \mathrm{L}{ }^{-1}$ during CHAOS1-springs (Table 1 ).

Nitrite and ammonium were in general higher during CHAOS1-springs, whereas no important differences were observed for phosphate and silicate between cruises (Fig. 8). The vertical distribution of nitrate concentration and vertical diffusivity was used to compute the input of nitrate into the upper layer through turbulent diffusivity (see Methods). During both cruises vertical diffusive fluxes peaked close to the low tide (Fig. 9). Regardless of the time window considered for the calculation, and therefore the number of microturbulence profiles, nitrate diffusive fluxes were on average higher during spring than neap tides. The averaged nitrate flux, computed by using the time interval of 40 min, was almost four times higher during spring (35 [17- 


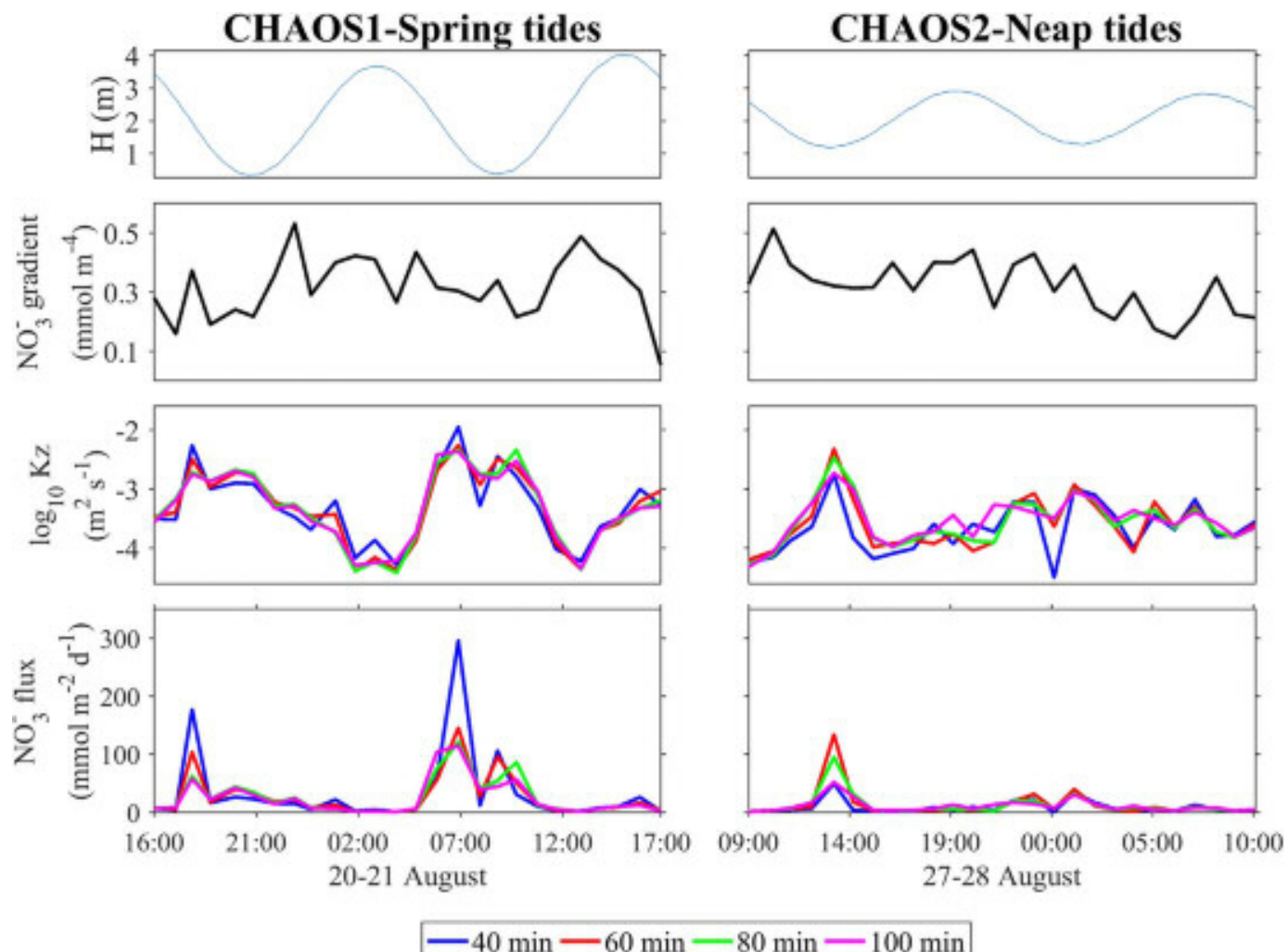

Fig. 9. Temporal variability of the vertical nitrate gradient, averaged vertical diffusivity (Kz), and nitrate diffusive flux computed during spring (CHAOS1) and neap (CHAOS2) tides in August 2013. Different time intervals (40 min, 60 min, 80 min, and 100 min) used for computing averaged Kz are indicated (see Methods). Tidal height for both periods is represented at the top panels. Horizontal scale corresponds to Coordinated Universal Time (UTC). [Color figure can be viewed at wileyonlinelibrary.com]

73] $\mathrm{mmol} \mathrm{m}^{-2} \mathrm{~d}^{-1}$ ) compared to neap tides (9 [6-15] mmol $\left.\mathrm{m}^{-2} \mathrm{~d}^{-1}\right)$. This time interval represents a compromise between the number of available microturbulence profiles for computing the $\mathrm{Kz}$ average, and the time lag between two consecutive nutrient samples collection.

\section{Phytoplankton community size-structure and composition}

Due to the influence of the intensifying upwelling, maximum Chl $a$ values were higher $\left(>10 \mathrm{mg} \mathrm{m}^{-3}\right.$ ) both at the outer (Fig. 7) and central stations (Fig. 6) during CHAOS2neaps, and clear differences were observed in the vertical distribution. During CHAOS1-springs higher values were located at the subsurface (ca. 10-20 m), whereas at the second cruise maximum values were sampled in the upper $10 \mathrm{~m}$. As the result of these patterns, no significant differences were observed in depth-integrated Chl $a$ between cruises (Table 1), with the $>20 \mu \mathrm{m}$ size-fraction representing about $80 \%$ of total Chl $a$ during both periods. Depth-integrated photosynthetic pigments concentration, derived from HPLC analysis, revealed that fucoxanthin was the most abundant ( 90\%) carotenoid (Supporting Information Fig. 2), indicating that the phytoplankton community was overwhelmingly dominated by diatoms during both cruises.

Microscopic taxonomic identification and counting revealed notable differences in both the abundance and vertical distribution of the different phytoplankton species between CHAOS1-springs and CHAOS2-neaps (Fig. 10). Higher cell densities were observed in the upper $20 \mathrm{~m}$ with cell maxima of small-sized Chaetoceros spp. $\left(8.6 \times 10^{5}\right.$ cells $\mathrm{L}^{-1} ; 2 \mathrm{~m}$ depth) during CHAOS1-springs and medium-sized Chaetoceros spp. $\left(6.6 \times 10^{5}\right.$ cells $\mathrm{L}^{-1} ; 12 \mathrm{~m}$ depth) during CHAOS2-neaps. A dramatic decrease of Chaetoceros socialis abundance was observed during CHAOS2-neaps, and conversely, an increase of large-sized Chaetoceros spp. was evidenced. Moreover, the statistical analysis of the phytoplankton community structure showed a clear separation between the two cruises and an important dissimilarity among CHAOS2-neaps samples (Fig. 11; nMDS: stress $=0.14)$. These differences were statistically significant (ANOSIM: $R=0.169, p<0.01$ ), and were due to the relative contributions of small-sized Chaetoceros spp. (27.9\%), Pseudonitzschia spp. (23.5\%), medium-sized Chaetoceros spp. (15.4\%), Chaetoceros socialis (9.8\%), and large-sized Chaetoceros spp. (4.6\%), as revealed by the SIMPER analysis. 


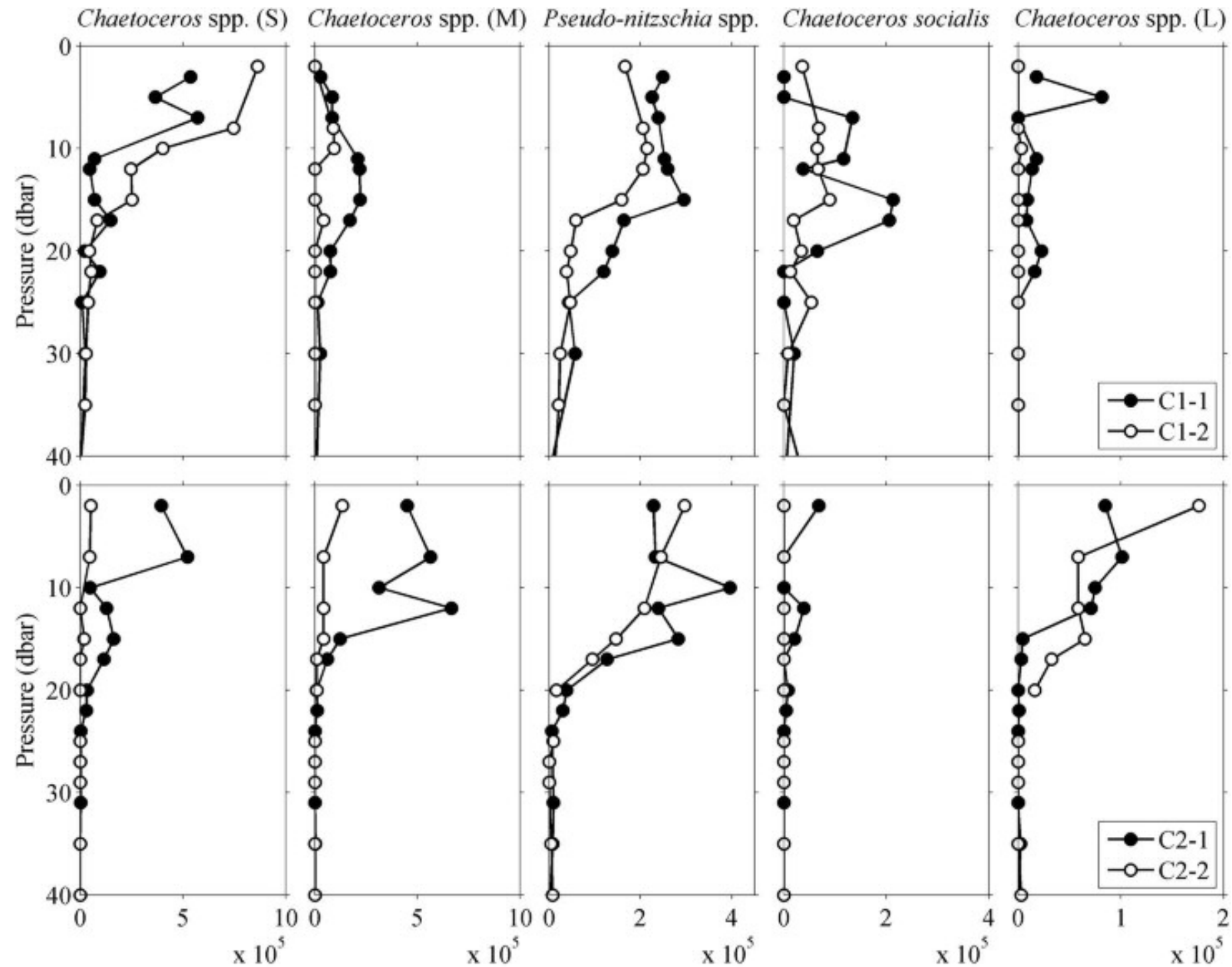

Abundance (cells L ${ }^{-1}$ )

Fig. 10. Vertical profiles of the five most abundant microphytoplankton groups observed at the beginning (1) and the end (2) of spring (CHAOS1, C1) and neap (CHAOS2, C2) tides sampled in August 2013. (S), (M), and (L) correspond to small, medium and large size.

The composition of the smaller picoplankton groups did not differ between cruises (Table 1). Picoplankton biomass was dominated by heterotrophic HNA (ca. 55\%) and LNA bacteria (ca. 40\%) during both cruises, whereas large picoeukaryotes were the dominant autotrophic picoplankton group $(3-7 \%)$.

\section{Discussion}

Internal wave activity in the Ría de Vigo during spring and neap tides

Our analysis of internal wave activity derived from SAR imagery confirmed the results from previous studies which first described the occurrence of internal wave activity in the Ría de Vigo (Fraga 1996; Barton et al. 2001; Varela et al. 2005). Moreover, the proxy for internal wave energy revealed that, during the summer months of the 2008-2011 period, ISW packets were more energetic during spring than neap tides. The averaged energy proxy values when discriminating over different wind speed intervals agree with the overall averaged values for spring and neap tides.

The methodology used for the calculation of the internal waves energy proxy described in this study has been previously used to investigate the internal wave activity in the Bay of Biscay (New and da Silva 2002) and the Estremadura Promontory (Magalhaes and da Silva 2012). However, as far 


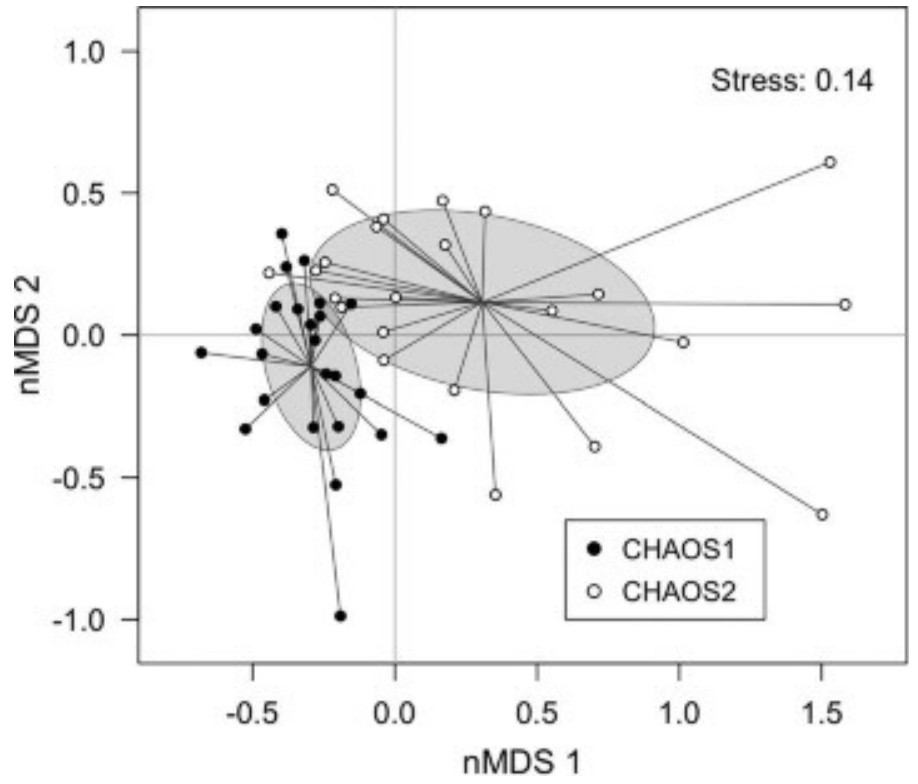

Fig. 11. Two-dimensional representation of the nMDS analysis. Shaded ellipses show $95 \%$ confidence intervals around sample group centroids.

as we know, this is the first time that this approach is used to analyze differences in internal wave energy between spring and neap tides. Our results are in agreement with previous studies carried out in the Celtic Sea (Pingree et al. 1984), the Bay of Biscay (New and da Silva 2002), and the Mascarene Ridge (da Silva et al. 2011), where internal waves activity was reported to be more important during spring tides. However, they contradict other studies based on thermistor chain moorings deployed farther south the Portuguese shelf $\left(41^{\circ} \mathrm{N}\right)$, describing no significant differences in internal wave amplitudes during spring and neap tides (Jeans and Sherwin 2001a,b). The present data set suggests a more energetic internal wave field in spring tides, but larger datasets should yield detailed comparisons, in particular, concerning the full range of wind speeds available for sea surface detection of internal waves in SAR imagery.

Our results also support previous observations carried out by Barton et al. (2001) who indicated that the internal wave regime off the Rías is less clear than that observed at $41^{\circ} \mathrm{N}$ in the Portuguese shelf, causing less internal wave crest coherence. These authors proposed that processes involving the Galicia Bank and three-dimensional features along the shelf edge influence internal tide generation in this region. Our analysis indicated that the most energetic internal wave packets were located, during both spring and neap tides, close to the $100 \mathrm{~m}$ and $150 \mathrm{~m}$ isobaths over the shelf and just off the Ría de Vigo. Future studies specifically addressing the generation sites and propagation patterns of internal waves (New and da Silva 2002; Azevedo et al. 2006; da Silva et al. 2007; Magalhaes and da Silva 2012) in this region would be very valuable in order to understand their role as key components of the variability in physical, chemical, and biological fields.

\section{Role of internal waves on mixing, nutrient supply and} phytoplankton composition

The CHAOS cruises were planned to take place in the summer because, due to the thermal stratification, this season is favorable for internal wave propagation (Moum et al. 2008). Furthermore, given that thermal stratification causes low surface nutrient concentration, nutrient supply associated with internal wave activity during this period should drive detectable increases in phytoplankton biomass and activity. However, from April to September, the upwelling situation prevails in the Ría de Vigo. Upwelling events reduce stratification and inject nutrients into the surface, masking the potential fertilization effect of internal waves. In fact, our study covered a transitional period from relaxation-stratification (CHAOS1-springs) to intensifying upwelling (CHAOS2-neaps). Besides the different hydrographic conditions that characterized both sampling periods, our results point to internal wave activity to be higher during CHAOS1-springs. Larger vertical displacements $(\sim 10 \mathrm{~m})$ of the isotherms observed during the first cruise over short time intervals (ca. 25-50 min), as well as increased turbulence and mixing levels at intermediate depths close to the low tide (Fig. 6), suggest that these disturbances could be associated with solitons. However, we cannot discard that other mechanisms typically at work in estuaries, such as those related to tidal and wind-induced circulation (Simpson et al. 1990; Scully et al. 2005), could also contribute to the enhanced mixing observed during spring tides.

Our results also showed that increased mixing levels during spring tides generate pulses of nitrate diffusive supply close to the low tide (Fig. 9), resulting in an averaged flux (35 [17-73] mmol m${ }^{-2} \mathrm{~d}^{-1}$ ) almost four times higher than during neap tides $\left(9[6-15] \mathrm{mmol} \mathrm{m}^{-2} \mathrm{~d}^{-1}\right.$ ). These differences were mainly determined by the variability in vertical diffusivity at intermediate depths of the water column, since the variability in the vertical nitrate gradient was comparatively smaller. Our results are in agreement with the observations carried out by Sharples et al. (2007), who reported higher fluxes of nitrate during spring $\left(9 \mathrm{mmol} \mathrm{m}^{-2} \mathrm{~d}^{-1}\right)$ compared to neap $\left(1.3 \mathrm{mmol} \mathrm{m} \mathrm{m}^{-2} \mathrm{~d}^{-1}\right)$ tides at the shelf edge of the Celtic Sea in summer 2005. Moreover, the nitrate diffusive fluxes computed during the CHAOS cruises were in the upper range of values computed for the Ría de Vigo during a seasonal study [0.13-15.50 $\mathrm{mmol} \mathrm{m} \mathrm{m}^{-2} \mathrm{~d}^{-1}$; Cermeño et al. (2016), and about one order of magnitude higher than the mean values calculated for the tropical and subtropical regions during the Malaspina expedition $(0.171 \pm 190 \mathrm{mmol}$ $\mathrm{m}^{-2} \mathrm{~d}^{-1}$; Fernández-Castro et al. (2014)], by using the same methodology for calculation. On the other hand, it is important to note that the use of one dimensional approaches has serious limitations in eastern boundary regions, where 
horizontal processes are significant (Lucas et al. 2011a; Fernández-Castro et al. 2016). In order to have an estimation of nitrate supply due to vertical advection linked to upwelling, we used a simplified box model (see Methods). Nitrate supply through advection computed in CHAOS1-springs (31 mmol $\mathrm{m}^{-2} \mathrm{~d}^{-1}$ ) was similar to the diffusive flux computed for the same cruise. However, under upwelling conditions during CHAOS2-neaps, the nitrate supply through advection (92 mmol $\mathrm{m}^{-2} \mathrm{~d}^{-1}$ ) was 10 -fold higher than the diffusive flux. As a result of both diffusive and advective processes, nitrate availability in the upper layer was more than 50\% higher during CHAOS2-neaps.

Despite the relatively large differences in nitrate availability between cruises, our results did not show significant changes in the size-structure of the phytoplankton community, derived from pigments composition. Microphytoplankton (> $20 \mu \mathrm{m}$ ) cells, mainly diatoms, dominated the phytoplankton community during CHAOS1-springs and CHAOS2-neaps ( $\sim 80 \%)$. Picophytoplankton biomass, which contributed about $\sim 2 \%$ to total $\mathrm{Chl} a$, was dominated by large picoeukaryotes in both cruises. However, the community species composition was significantly different between cruises. In CHAOS1-springs, when the water column was stratified, small-sized diatoms such as Chaetoceros socialis and smallsized Chaetoceros spp. were more abundant. These species were replaced by larger ones (medium and large Chaetoceros spp.) when a strong upwelling pulse occurred one week later during CHAOS2-neaps. This is consistent with the species succession characteristic of the upwelling-relaxation-stratification transition previously described for the summer period in this region (Figueiras and Niell 1987; Figueiras et al. 2002; Pitcher et al. 2010). Typically, chain-forming diatoms of medium and large size dominate during upwelling events, when stratification is weak and nutrient availability is high. During subsequent transient periods of relaxation and stratification, smaller diatoms and heterotrophic species coexist. Conversely, the transition between upwelling and downwelling seasons (end of September - beginning of October) is characterized by dinoflagellates, some of them potentially producers of harmful algae blooms. Previous studies suggested that nutrient input through vertical diffusion from below the nutricline during upwelling relaxation, as well as short-term variability in the intermittency of the upwelling, could contribute to explain the continuous dominance of large-sized phytoplankton during the upwelling favorable season (Figueiras and Pazos 1991; Cermeño et al. 2006). In this regard, chemostat laboratory experiments have shown that the frequency of nitrate pulses, and not only the magnitude of the nitrate supply, controls the competitive dynamics of phytoplankton, with intermittent nutrient supply favoring fast-growing phytoplankton such as diatoms (Cermeño et al. 2011). A complex short-term variability of the hydrographic and biogeochemical conditions is present in upwelling regimes, which in turn forces significant changes in phytoplankton distribution and composition. Separating the effects of hydrodynamic processes (i.e., advection) and in situ growth (in response to nutrient and light availability) on phytoplankton assemblages becomes a difficult task due to the tight coupling between these two processes.

Horizontal and vertical internal-wave-mediated fluxes may become the primary nitrate supply mechanism in those eastern boundary regions where the advective nutrient supply is weak, or during times when the typically dominant advective forcing is temporarily quiescent (Lucas et al. 2011a,b). In this regard, the horizontal nitrate flux driven by the internal tide has been identified as the main mechanism supporting new primary production in the Southern California Bight, where the wind-forced upwelling is generally weak (Lucas et al. 2011b). In the Ría de Vigo our results suggest that especially during spring tides and stratification conditions, enhanced mixing driven by internal waves could represent an important fertilizing mechanism of the euphotic layer. Considering the average gross primary production reported for this region under summer stratification conditions (ca. $5051 \mathrm{mg} \mathrm{C} \mathrm{m}^{-2}$ $\mathrm{d}^{-1}$; Marañón et al. 2004), and comparing it with the averaged nitrate diffusive flux computed for CHAOS1-springs (35 mmol $\mathrm{m}^{-2} \mathrm{~d}^{-1}$ ) by assuming Redfield stoichiometry, we calculate that about $50 \%$ of the organic matter synthesized during this period could be sustained by enhanced nitrate diffusive supply during spring tides. Hence, our results suggest that even in regions under the influence of coastal upwelling, characterized by strong advective circulation, turbulent mixing driven by internal waves could play an important role in controlling the dynamics of phytoplankton productivity and community structure.

\section{References}

Álvarez-Salgado, X. A., J. Gago, B. M. Míguez, M. Gilcoto, and F. F. Pérez. 2000. Surface waters of the NW Iberian margin: Upwelling on the shelf versus outwelling of upwelled waters from the Rías Baixas. Estuar. Coast. Shelf Sci. 51: 821-837. doi:10.1006/ecss.2000.0714

Álvarez-Salgado, X. A., and others. 2002. New production of the NW Iberian shelf during the upwelling season over the period 1982-1999. Deep-Sea Res. Part I Oceanogr. Res. Pap. 49: 1725-1739. doi:10.1016/S0967-0637(02)00094-8

Álvarez-Salgado, X. A., and others. 2003. The Portugal coastal counter current off NW Spain: New insights on its biogeochemical variability. Prog. Oceanogr. 56: 281-321. doi:10.1016/S0079-6611(03)00007-7

Arístegui, J., and others. 2009. Sub-regional ecosystem variability in the Canary Current upwelling. Prog. Oceanogr. 83: 33-48. doi:10.1016/j.pocean.2009.07.031

Azevedo, A., J. C. B. da Silva, and A. L. New. 2006. On the generation and propagation of internal solitary waves in the southern Bay of Biscay. Deep-Sea Res. Part I Oceanogr. Res. Pap. 53: 927-941. doi:10.1016/j.dsr.2006.01.013 
Barton, E. D., M. E. Inall, T. J. Sherwin, and R. Torres. 2001. Vertical structure, turbulent mixing and fluxes during Lagrangian observations of an upwelling filament system off Northwest Iberia. Prog. Oceanogr. 51: 249-267. doi: 10.1016/S0079-6611(01)00069-6

Blanton, J. O., K. R. Tenore, F. Castillejo, L. P. Atkinson, F. B. Schwing, and A. Lavin. 1987. Relationship of upwelling to mussel production in the Rias on the western coast of Spain. J. Mar. Res. 45: 497-511. doi:10.1357/002224087788401115

Brandt, P., R. Romeiser, and A. Rubino. 1999. On the determination of characteristics of the interior ocean dynamics from radar signatures of internal solitary waves. J. Geophys. Res. 104: 39-45. doi:10.1029/1999JC900092

Calvo-Díaz, A., and X. A. G. Morán. 2006. Seasonal dynamics of picoplankton in shelf waters of the southern Bay of Biscay. Aquat. Microb. Ecol. 42: 159-174. doi:10.3354/ ame042159

Cermeño, P., E. Marañón, V. Pérez, P. Serret, E. Fernández, C. G. Castro. 2006. Phytoplankton size structure and primary production in a highly dynamic coastal ecosystem (Ría de Vigo, NW-Spain): Seasonal and short-time scale variability. Estuar. Coast. Shelf Sci. 67: 251-256. doi: 10.1016/j.ecss.2005.11.027

Cermeño, P., J.-B. Lee, K. Wyman, O. Schofield, and P. G. Falkowski. 2011. Competitive dynamics in two species of marine phytoplankton under non-equilibrium conditions. Mar. Ecol. Prog. Ser. 429: 19-28. doi:10.3354/meps09088

Cermeño, P., P. Chouciño, B. Fernández-Castro, F. G. Figueiras, E. Marañón, C. Marrase, B. Mouriño-Carballido, M. Pérez-Lorenzo, T. Rodríguez-Ramos, I. G. Teixeira, and S. M. Vallina. 2016. Marine primary productivity is driven by a selection effect. Front. Mar. Sci. 3: 173. doi:10.3389/ fmars.2016.00173

Clarke, K. R. 1993. Non-parametric multivariate analyses of changes in community structure. Aust. J. Ecol. 18: 117143. doi:10.1111/j.1442-9993.1993.tb00438.x

da Silva, J. C. B., S. A. Ermakov, I. S. Robinson, and S. V. Kijash. 1998. Role of surface films in ERS SAR signatures of internal waves on the shelf 1 . Short-period internal waves. J. Geophys. Res. 103: 8009-8031. doi:10.1029/2000JC900053

da Silva, J. C. B., A. L. New, and A. Azevedo. 2007. On the role of SAR for observing "local generation" of internal solitary waves off the Iberian Peninsula. Can. J. Remote Sens. 33: 388-403. doi:10.5589/m07-041

da Silva, J. C. B., A. L. New, and J. M. Magalhaes. 2011. On the structure and propagation of internal solitary waves generated at the Mascarene Plateau in the Indian Ocean. Deep-Sea Res. Part I Oceanogr. Res. Pap. 58: 229-240. doi: 10.1016/j.dsr.2010.12.003

Fernández-Castro, B., B. Mouriño-Carballido, V. M. BenítezBarrios, P. Chouciño, E. Fraile-Nuez, R. Graña, M. Piedeleu, and Á. Rodríguez-Santana. 2014. Microstructure turbulence and diffusivity parameterization in the tropical and subtropical Atlantic, Pacific and Indian Oceans during the
Malaspina 2010 expedition. Deep-Sea Res. Part I Oceanogr. Res. Pap. 94: 15-30. doi:10.1016/j.dsr.2014.08.006

Fernández-Castro, B., J. Arístegui, L. Anderson, M. F. Montero, S. Hernández-León, E. Marañón, and B. MouriñoCarballido. 2016. Mesopelagic respiration at the ESTOC (European Station for Time-Series in the Ocean, $15.5 \mathrm{~W}$, $29.1 \mathrm{~N})$ site inferred from a tracer conservation model. Deep-Sea Res. I 115: 63-73. doi:10.1016/j.dsr.2016.05.010

Figueiras, F. G., and F. X. Niell. 1987. Composición del fitoplancton de la ría de Pontevedra. Investig. Pesq. 51: 371-409.

Figueiras, F. G., and Y. Pazos. 1991. Microplankton assemblages in three Rias Baixas (Vigo, Arosa and Muros, Spain) with a subsurface chlorophyll maximum: their relationships to hydrography. Mar. Ecol. Prog. Ser. 76: 219-233. doi:10.3354/meps076219

Figueiras, F. G., U. Labarta, and M. J. Fernández Reiriz. 2002. Coastal upwelling, primary production and mussel growth in the Rías Baixas of Galicia. Hydrobiologia. 484: 121131. doi:10.1023/A:1021309222459

Fraga, F. 1981. Upwelling off the Galician Coast, Northwest Spain. Coast. Estuarines Sci. 1: 176-182. doi:10.1029/co001p0176

Fraga, S. 1996. Ondas internas en la plataforma frente a la Ría de Vigo, y posibles consecuencias ecológicas. Sci. Mar. 60: 543-547.

Grasshoff, K., K. Kremling, and M. Ehrhardt. 1983. Methods of seawater analysis. Verlag Chemie $\mathrm{GmbH}$.

Jeans, D. R. G., and T. J. Sherwin. 2001a. The variability of strongly non-linear solitary internal waves observed during an upwelling season on the Portuguese shelf. Cont. Shelf Res. 21: 1855-1878. doi:10.1016/S0278-4343(01)00026-7

Jeans, D. R. G., and T. J. Sherwin. 2001b. The evolution and energetics of large amplitude nonlinear internal waves on the Portuguese shelf. J. Mar. Res. 59: 327-353. doi: 10.1357/002224001762842235

Latasa, M. 2007. Improving estimations of phytoplankton class abundances using CHEMTAX. Mar. Ecol. Prog. Ser. 329: 13-21. doi:10.3354/meps329013

Legendre, P., and L. Legendre. 1988. Numerical Ecology, Second Edition, Elsevier Science BV.

Lucas, A. J., C. L. Dupont, V. Tai, J. L. Largier, B. Palenik, and P. J. S. Franks. 2011a. The green ribbon: Multiscale physical control of phytoplankton productivity and community structure over a narrow continental shelf. Limnol. Oceanogr. 56: 611-626. doi:10.4319/lo.2011.56.2.0611

Lucas, A. J., P. J. S. Franks, and C. L. Dupont. 2011b. Horizontal internal-tide fluxes support elevated phytoplankton productivity over the inner continental shelf. Limnol. Oceanogr. Fluids Environ. 1: 56-74. doi:10.1215/ 21573698-1258185

Magalhaes, J. M., and J. C. B. da Silva. 2012. SAR observations of internal solitary waves generated at the Estremadura Promontory off the west Iberian coast. Deep-Sea Res. Part I Oceanogr. Res. Pap. 69: 12-24. doi:10.1016/j.dsr.2012.06.002

Marañón, E., P. Cermeño, E. Fernández, J. Rodríguez, and L. Zabala. 2004. Significance and mechanisms of 
photosynthetic production of dissolved organic carbon in a coastal eutrophic ecosystem. Limnol. Oceanogr. 49: 1652-1666. doi:10.4319/1o.2004.49.5.1652

Moum, J. N., J. Nash, and J. Klymak. 2008. Small-scale processes in the coastal ocean. Oceanography 21: 22-33. doi: 10.5670/oceanog.2008.02

New, A. L., and J. C. B. da Silva. 2002. Remote-sensing evidence for the local generation of internal soliton packets in the central Bay of Biscay. Deep-Sea Res. Part I Oceanogr. Res. Pap. 49: 915-934. doi:10.1016/S0967-0637(01)00082-6

Norland, S. 1993. The relationship between biomass and volume of bacteria, p. 303-307. In P. F. Kemp, B. F. Sherr, E. B. Sherr and J. J. Cole [eds.], Handbook of methods in aquatic microbial ecology. Lewis Publishers.

Osborn, T. R. 1980. Estimates of the local rate of vertical diffusion from dissipation measurements. Oceanography 10: 83-89. doi:10.1175/1520-0485(1980)010<0083:eotlro >2.0.co;2

Pitcher, G. C. C., F. G. Figueiras, B. M. Hickey, and M. T. T. Moita. 2010. The physical oceanography of upwelling systems and the development of harmful algal blooms. Prog. Oceanogr. 85: 5-32. doi:10.1016/j.pocean.2010.02.002

Pingree, R. D., D. K. Griffiths, and G. T. Mardell. 1984. The structure of the internal tide at the Celtic Sea shelf break. J. Mar. Biol. Assoc. United Kingdom 64: 99-113. doi: 10.1017/s002531540005966x

Prandke, H., and A. Stips. 1998. Test measurements with an operational microstructure-turbulence profiler: Detection limit of dissipation rates. Aquat. Sci. 60: 191-209. doi: 10.1007/s000270050036

R Development Core Team. 2016. R: A Language and Environment for Statistical Computing. Foundation for Statistical Computing, Vienna, Austria. https://www.R-project. org/.

Robinson, I. S., and J. C. B. da Silva. 2010. Internal waves, p. 453-483. In P. Blondel [ed.], Discovering the ocean from space: The unique applications of satellite oceanography. Springer Berlin Heidelberg.

Scully, M. E., C. Friedrichs, and J. Brubaker. 2005. Control of estuarine stratification and mixing by wind-induced straining of the estuarine density field. Estuaries 28: 321326. doi: $10.2307 / 3526916$

Sharples, J., and others. 2007. Spring-neap modulation of internal tide mixing and vertical nitrate fluxes at a shelf edge in summer. Limnol. Oceanogr. 52: 1735-1747. doi: 10.4319/1o.2007.52.5.1735

Sharples, J., C. M. Moore, A. E. Hickman, P. M. Holligan, J. F. Tweddle, M. R. Palmer, and J. H. Simpson. 2009. Internal tidal mixing as a control on continental margin ecosystems. Geophys. Res. Lett. 36: 1-5. doi:10.1029/2009GL040683

Simpson, J. H., J. Brown, J. Matthews, and G. Allen. 1990. Stirring in the control of estuarine stratification. Estuaries 13: $125-132$. doi:10.2307/1351581

Utermöhl, H. 1931. Neue Wege in der quantitativen Erfassung des Planktons. Verh. Int. Verein. Theor. Angew. Limnol. 5: 567-596.

Varela, M. 1992. Upwelling and phytoplankton ecology in Galician (NW Spain) rias and shelf waters. Boletín Inst. Español Oceanogr. 8: 57-74.

Varela, R. A., G. Rosón, J. L. Herrera, S. Torres-López, and A. Fernández-Romero. 2005. A general view of the hydrographic and dynamical patterns of the Rías Baixas adjacent sea area. J. Mar. Syst. 54: 97-113. doi:10.1016/ j.jmarsys.2004.07.006

Wooster, W. S., A. Bakun, and D. R. McClain. 1976. The seasonal upwelling cycle along the eastern boundary of the North Atlantic. J. Mar. Res. 34: 131-146.

Worden, A. Z., J. K. Nolan, and B. Palenik. 2004. Assessing the dynamics and ecology of marine picophytoplankton: The importance of the eukaryotic component. Limnol. Oceanogr. 49: 168-179. doi:10.4319/lo.2004.49.1.0168

Zapata, M., F. Rodríguez, and J. L. Garrido. 2000. Separation of chlorophylls and carotenoids from marine phytoplankton: A new HPLC method using a reversed phase C8 column and pyridine-containing mobile phases. Mar. Ecol. Prog. Ser. 195: 29-45. doi:10.3354/meps195029

\section{Acknowledgments}

We are grateful to all the technicians, researchers and crew on board the R/V Mytilus involved in the data collection. We thank the detailed comments provided by two anonymous reviewers during the revision process. M. Villamaña acknowledges the receipt of a FPU fellowship (FPU014/05385) from the Spanish Ministry of Education, Culture and Sports. P. Cermeño thanks a Ramón y Cajal contract from Spanish Ministry of Economy and Competitiveness. J.M. Magalhaes is grateful for a Portuguese FCT research grant (SFRH/BPD/84420/2012). Funding for this study was provided by the Spanish Ministry of Economy and Competitiveness under the research project CTM2012-30680 to B. MouriñoCarballido.

\section{Conflict of Interest}

None declared.

Submitted 28 April 2016 Revised 21 September 2016 Accepted 25 October 2016 Associate editor: Craig Stevens 